\title{
Gas buildup in Lake Nyos, Cameroon: The recharge process and its consequences
}

\author{
W. C. Evans \\ U.S. Geological Survey, Menlo Park, CA 94025, U.S.A. \\ G. W. KLING \\ Department of Biology, University of Michigan, Ann Arbor, MI 48109, U.S.A. \\ M. L. Tuttle \\ U.S. Geological Survey, Denver, CO 80225, U.S.A. \\ G. TANYILEKE \\ Institute for Geological and Mining Research, Yaounde B.P. 4110, Cameroon \\ and \\ L. D. WHITE \\ U.S. Geological Survey, Menlo Park, CA 94025, U.S.A.
}

(Received 31 December 1991; accepted in revised form 12 August 1992)

\begin{abstract}
The gases dissolved in Lake Nyos, Cameroon, were quantified recently (December 1989 and September 1990) by two independent techniques: in-situ measurements using a newly designed probe and laboratory analyses of samples collected in pre-evacuated stainless steel cylinders. The highest concentrations of $\mathrm{CO}_{2}$ and $\mathrm{CH}_{4}$ were $0.30 \mathrm{~mol} / \mathrm{kg}$ and $1.7 \mathrm{mmol} / \mathrm{kg}$, respectively, measured in cylinders collected $1 \mathrm{~m}$ above lake bottom. Probe measurements of in-situ gas pressure at three different stations showed that horizontal variations in total dissolved gas were negligible. Total dissolved-gas pressure near the lake bottom is $1.06 \mathrm{MPa}(10.5 \mathrm{~atm}), 50 \%$ as high as the hydrostatic pressure of $2.1 \mathrm{MPa}$ (21 atm). Comparing the $\mathrm{CO}_{2}$ profile constructed from the 1990 data to one obtained in May 1987 shows that $\mathrm{CO}_{2}$ concentrations have increased at depths below $150 \mathrm{~m}$. Based on these profiles, the average rate of $\mathrm{CO}_{2}$ input to bottom waters was $2.6 \times 10^{8} \mathrm{~mol} / \mathrm{a}$. Increased deep-water temperatures require an average heat flow of $0.32 \mathrm{MW}$ into the hypolimnion over the same time period. The transport rates of $\mathrm{CO}_{2}$, heat, and major ions into the hypolimnion suggest that a low-temperature reservoir of free $\mathrm{CO}_{2}$ exists a short distance below lake bottom and that convective cycling of lake water through the sediments is involved in transporting the $\mathrm{CO}_{2}$ into the lake from the underlying diatreme. Increased $\mathrm{CH}_{4}$ concentrations at all depths below the oxycline and a high ${ }^{14} \mathrm{C}$ content ( $41 \%$ modern) in the $\mathrm{CH}_{4} 4 \mathrm{~m}$ above lake bottom show that much of the $\mathrm{CH}_{4}$ is biologically produced within the lake. The $\mathrm{CH}_{4}$ production rate may vary with time, but if the $\mathrm{CO}_{2}$ recharge rate remains constant, $\mathrm{CO}_{2}$ saturation of the entire hypolimnion below $50 \mathrm{~m}$ depth would require $\sim 140$ a, given present-day concentrations.
\end{abstract}

\section{INTRODUCTION}

The Devastating release of $\mathrm{CO}_{2}$ from Lake Nyos (Fig. 1) on 21 August 1986 resulted in the deaths of 1700 pecple. Overshadowing a smaller but similar event at Lake Monoun on 15 August 1984 (SIGURDSson et al., 1987), the Lake Nyos disaster attracted international attention, and the results of a number of scientific studies have recently been compiled (LE Guern and Sigvaldason, 1989, 1990). Debate focused on whether the disaster was caused by a volcanic (phreatic) eruption from beneath the maar lake (TAZIEFF, 1989; BARBERI et al., 1989), a limnological disturbance releasing magmatic $\mathrm{CO}_{2}$ previously stored within the lake (TUTrLE et al., 1987; TIETZE,
1987: Kling et al , , 1987, 1989; KUSAKABE et al., 1989; GigGENBACH, 1990), or a combination of both processes (FreETH and KAY, 1987).

One test of the limnological hypothesis involves the recharge of $\mathrm{CO}_{2}$ into the lake. While a long-term flux of $\mathrm{CO}_{2}$ into bottom waters is compatible with the volcanic eruption theory, it is critical to the limnological explanation. If the gas was slowly building up within the lake at the time of the gas burst, the influx of gas from below should continue after the burst. To test the validity of the limnological hypothesis and to gauge the likelihood of a recurrent gas burst from Lake Nyos, one of the most important parameters to monitor is dissolved gas pressure in the hypolimnion. Partly because the gas pressures are much higher 


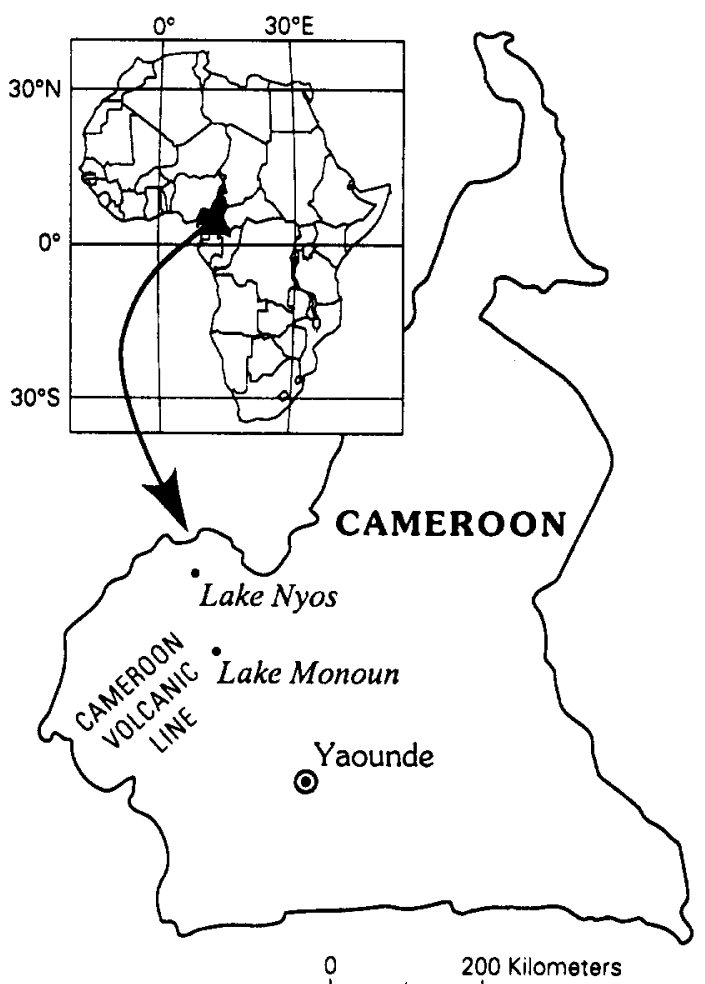

Fig. 1. Map of Cameroon showing lake locations.

than those usually encountered in lakes, accurate measurement of the dissolved gases has proven very difficult.

\section{Previous gas studies}

The earliest gas samples collected in September 1986, two weeks after the burst, showed that $\mathrm{CO}_{2}$ comprised $>99 \%$ of the gas dissolved in the hypolimnion (TutTle et al., 1987), but gas-to-water ratios were not measured. The amount of gas exsolved from subsurface water samples was first measured in October 1986 (KuSAKABE et al., 1989), and dissolved gas concentrations in pressurized samples were first measured in November 1986 (TIETZE, 1987). These studies demonstrated that the dissolved $\mathrm{CO}_{2}$ profile was similar to the profiles of temperature and total dissolved solids, which increase as a function of depth. To test for $\mathrm{CO}_{2}$ recharge, samples were collected in pre-evacuated stainless steel cylinders in January, March and May 1987 (KLING et al., 1989). At most depths, the $\mathrm{CO}_{2}$ profiles were similar to the one reported by TIETZE (1987). However, cylinders filled near lake bottom indicated fairly large (up to $50 \%$ ) horizontal variations in $\mathrm{CO}_{2}$ concentrations. This was puzzling in view of the smaller horizontal variations in temperature and ionic strength. At that time, it was not clear whether these $\mathrm{CO}_{2}$ variations existed in the lake or were caused by gas leakage from some of the cylinders. Before this question was resolved by later sampling (as discussed below), two cylinder samples were collected on a brief trip in June 1988.

NoJiRI et al. (1990) were successful in showing that $\mathrm{CO}_{2}$ concentrations in December 1988 at 190 and $200 \mathrm{~m}$ depths had increased from previous values, although the $200 \mathrm{~m}$ measurement was imprecise due to the large volume of gas exsolved. Extrapolating the $\mathrm{CO}_{2}$-TDS relation from $190 \mathrm{~m}$ depth to lake bottom at $210 \mathrm{~m}$, they calculated a $\mathrm{CO}_{2}$ flux into Lake Nyos of $5.15 \times 10^{8} \mathrm{~mol} / \mathrm{a}$, and later revised this to $1 \times 10^{9} \mathrm{~mol} / \mathrm{a}$ (NoIIRt et al., 1993). A higher $\mathrm{CO}_{2}$ flux $\left(2.0 \times 10^{9} \mathrm{~mol} / \mathrm{a}\right)$ was derived from the December 1988 measurements of temperature and dissolved $\mathrm{He}$ by SANO et al. (1990). These important studies documented $\mathrm{CO}_{2}$ recharge. However, the rate calculations involved an assumed relation between $\mathrm{CO}_{2}$ and another quantity actually measured (TDS or $\mathrm{He}$ ), and the possibility of horizontal variations in gas concentrations remained untested. Reported here are the results of two new gas surveys of Lake Nyos, carried out in December 1989 and September 1990, using numerous stainless steel cylinders and a new probe designed specifically for real-time measurements of dissolved gas pressure in the hypolimnion.

\section{METHODS OF SAMPLING AND ANALYSIS}

Three sampling stations were established on Lake Nyos in December 1989, one of which was reoccupied in September 1990. All stations were located in the central basin, an oval crater with a $0.4 \mathrm{~km}^{2}$ flat bottom at $210 \mathrm{~m}$ depth (Fig. 2). To assure verticality of the sampling line, three fluke-type anchors were set in a triangular pattern around each station. Temperature profiles were measured using a fourconductor thermistor ohm-meter (SASS et al., 1981) calibrated just prior to the neld trip and rechecked in the laboratory against a recently certified NBS-traceable thermometer at the conclusion of the trip. The error was within the $0.005^{\circ} \mathrm{C}$ readability of the thermometer. Samples of water were collected at various depths using a Niskin sampler equipped with a vent valve that allowed exsolving gas to escape during retrieval. Samples were handled as on previous occasions (KLING et al., 1989), i.e. with on-site filtration and alkalinity being titrated before there was any visible precipitation of solids.

\section{Cylinder procedures}

The stainless steel cylinders were fitted with two ball valves and one check valve (Fig. 3a). The top ball valve was attached to a trigger on the sampling line and could be opened at depth by a sliding messenger. With this valve open, hydrostatic pressure forces the check valve open (nominal cracking pressure is small, $7 \mathrm{kPa}$ ) and fluid enters the cylinder. When internal and external pressures are virtually equal, the check valve closes to trap the sample. Upon cylinder retrieval, the top ball valve was manually closed as a backup seal.

The concentrations of dissolved gases in the cylinders were determined in the laboratory after attaching a headspace cylinder to each sample cylinder (Fig. 3b). Sample fluids were equilibrated with the initially evacuated headspace at $25.0^{\circ} \mathrm{C}$ to partition the gases between solution and 
headspace. The partial pressures of the gases in the headspace were determined by gas chromatography using a thermal conductivity detector. Cylinder volumes are known and the ideal gas law was used to calculate the amount of each gas extracted, except for $\mathrm{CO}_{2}$ where the non-ideality correction of WeIss (1974) was made. The results were corrected for the gas remaining in solution using the solubility data of WeISS (1974) for $\mathrm{CO}_{2}$ and WILHELM et al. (1977) for other species. Following gas chromatographic analysis, $\mathrm{CO}_{2}$ and $\mathrm{CH}_{4}$ were collected by repeated extraction of the solution. Concentrations of $\mathrm{CO}_{2}$ previously calculated by gas chromatography were then verified by manometric measurement before the $\mathrm{CO}_{2}$ was analyzed isotopically. Extracted $\mathrm{CH}_{4}$ was converted to $\mathrm{CO}_{2}$ and $\mathrm{H}_{2}$ prior to isotope analysis. After gas extraction, the water was drained from the cylinders and a small amount analyzed for the $\mathrm{C}$-isotope composition of the $\mathrm{HCO}_{3}$ and any unextracted $\mathrm{CO}_{2}$. These results were used to make small corrections to the isotope composition of the extracted $\mathrm{CO}_{2}$ to generate $\delta^{13} \mathrm{C}$ values for the dissolved inorganic carbon (DIC). The remainder of the water was occasionally used for major-ion analysis. The analytical procedures for the cylinder samples were generally similar to those used previously on low-pressure samples described by Evans et al. (1988).

All cylinders were tested for leaks during evacuation prior to fieldwork. Ten cylinders were evacuated and stored for six months to test long-term leak rates; only one had an air leak rate $>20 \mu \mathrm{mol} / \mathrm{month}$. Two cylinders were further tested by sampling a pressurized test solution of $\mathrm{CO}_{2}$ charged, air-saturated water (ASW), from a large bomb. The $\mathrm{CO}_{2}$ pressure in the bomb was just over $0.4 \mathrm{MPa}$, in the range of subsurface samples from Lake Nyos. The $\mathrm{CO}_{2}$ concentrations measured in both cylinders were within $2 \%$ of the correct value and measured $\delta^{13} \mathrm{C}$ values on the DIC were $<0.1 \%$ in error. Measured amounts of the atmospheric gases, $\mathrm{N}_{2}$ and $\mathrm{Ar}$, deviated as much as $10 \%$ from the correct ASW values, indicating that there were minor

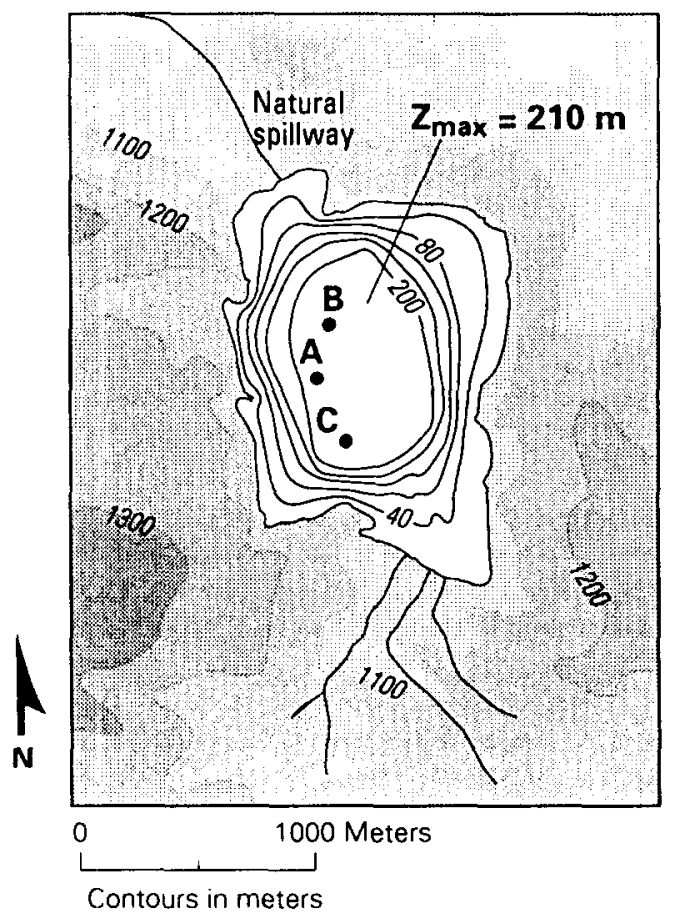

FIG. 2. Bathymetric map of Lake Nyos modified from TuTrLe et al. (1987) showing sampling stations A, B, and C on the 1989 and 1990 expeditions. Depths are from lowest point on the natural spillway.

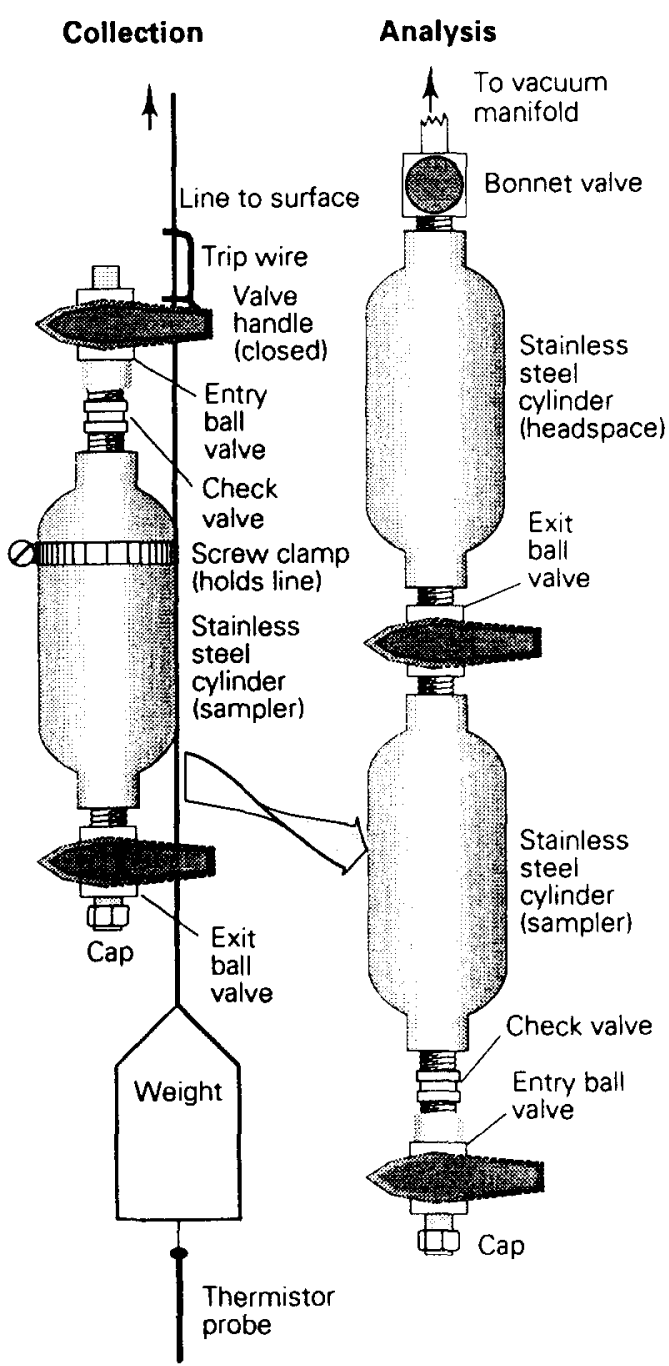

(a)

(b)

FIG. 3. (a) Sample cylinder deployed, (b) Sample prepared for analysis by attaching headspace cylinder.

problems associated with sampling these highly insoluble gases in the presence of large excess of $\mathrm{CO}_{2}$. Presumably, this applied also to $\mathrm{CH}_{4}$ in the samples from Lake Nyos. However, there was no evidence from laboratory testing that cylinder failure could explain the magnitude of the horizontal variations in dissolved gas observed in the 1987 studies.

\section{Probe procedures}

Plastic tubing has long been used as a semi-permeable membrane to monitor dissolved gases (ENNs et al., 1965); molecules of each gas species diffuse through the membrane until the fugacities inside the tubing and in the surrounding fluid are equal. The gas probe (Fig. 4) was constructed using medical-grade silicone tubing $1.47 \mathrm{~mm} \mathrm{I.D.} \mathrm{with} \mathrm{a} 0.24 \mathrm{~mm}$ wall thickness. The tubing was cut into $70-\mathrm{cm}$ lengths and 15 of these were attached by slip fit to short lengths of $1 / 16^{\prime \prime}$ O.D. stainless steel capillary tubing. Braided 18 -gauge steel wire was fed through the entire length of the silicone tubing and into the stainless steel capillary to prevent collapse of the silicone tubing under high hydrostatic pressure. The free ends of the silicone tubes were then plugged. The 15 


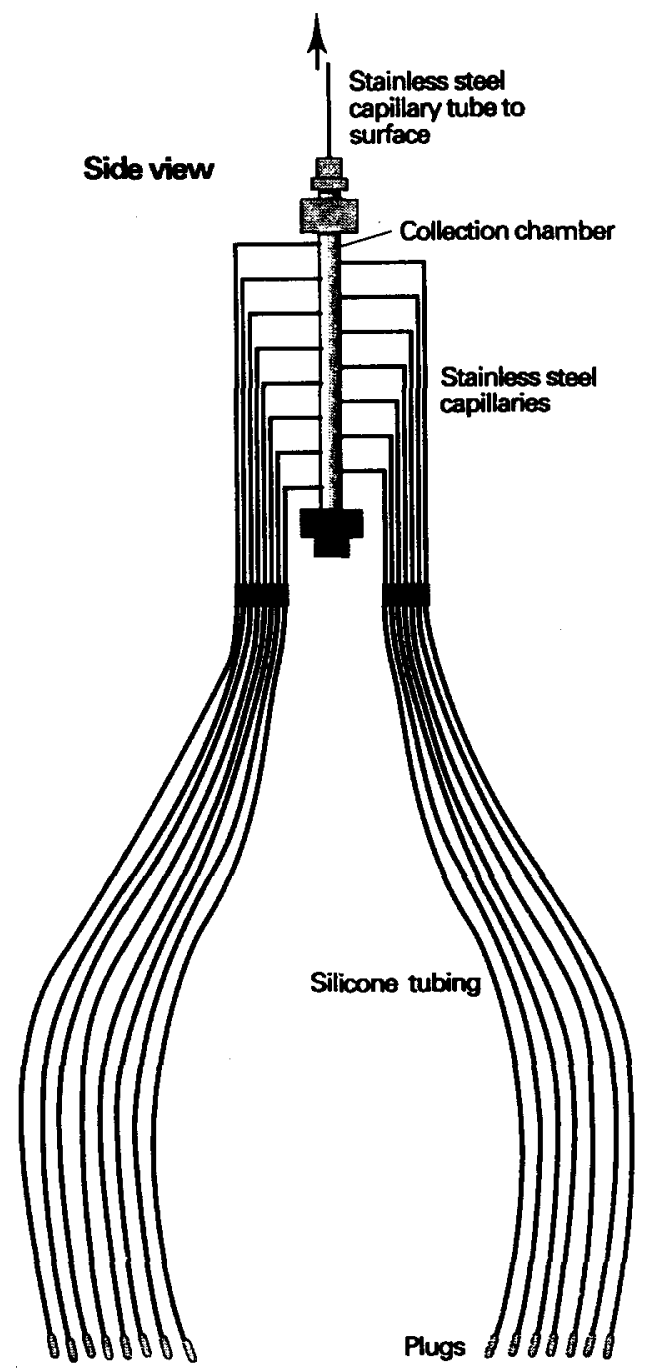

FIG. 4. Gas-pressure probe.

stainless steel capillaries were brazed to a $2 \mathrm{~cm}^{3}$ collection chamber, and the chamber in turn was connected to a $215-\mathrm{m}$ length of $1 / 16^{\prime \prime}$ O.D. stainless steel capillary tubing that was coiled on a reel. When the probe is immersed in water, gas diffuses through the probe and flows through the capillary tubing to a pressure gauge. The long capillary naturally causes gauge response to be slow. Laboratory testing with the probe sealed in a pressure bomb containing aqueous solutions of $\mathrm{CO}_{2}\left(p \mathrm{CO}_{2}=0.3-1.0 \mathrm{MPa}\right)$ showed that several hours were required for gauge pressure to equal dissolved gas pressure to within the accuracy of the gas $( \pm 10$ $\mathrm{kPa}$ ). However, gauge response curves were of such uniform shape that final pressures could be extrapolated after only $1 \mathrm{~h}$ with a total error of $\pm 15 \mathrm{kPa}$. When deployed, gauge pressures at the lake surface were less than gas pressure at depth because of the weight of the gas in the long column. Gauge pressures were corrected to in-situ pressures using:

$$
P_{0}=(P) \mathrm{e}^{-M g z / \mathrm{R} T}
$$

where $P_{0}$ is in-situ pressure, $P$ is gauge pressure, $M$ is the molecular weight of the gas, $g$ is the gravitational acceleration, $z$ is the measurement depth, $R$ is the gas constant and $T$ is absolute temperature. The gas is nearly pure $\mathrm{CO}_{2}$ and $M$ was assumed to be $44 \mathrm{~g} / \mathrm{mol}$. The calculated pressure correction is $3.7 \%$ at lake bottom.

\section{RESULTS AND DISCUSSION}

In Fig. 5, the 1989 and 1990 temperature profiles are compared to those from January and May 1987. Water chemistry data from selected depths are reported in Table 1. Figure 6 shows the profile of alkalinity (as $\mathrm{HCO}_{3}$ ) from all sampling dates and depths. Profiles of the other major ions are all similar to that of $\mathrm{HCO}_{3}$, which makes up $>98 \%$ of the anions.

The August 1986 gas burst coincided with a partial mixing between cool, dilute surface water and warm, mineralized bottom water affecting the temperature and chemical structure within the lake (TUTTLE et al., 1987; KLING et al., 1987). KLING et al. (1989) have discussed the changes that occurred in the ensuing nine months (to May 1987). Rainfall, runoff and surface mixing caused dilution and cooling of the subsurface water to a depth of about 20-30 m, while recharge from warm, mineralized fluid at lake bottom caused temperature and ionic strength to increase in the deepest layers. Between 30 and $175 \mathrm{~m}$ depth, temperature and water chemistry did not show significant changes. It was therefore assumed that transport of heat and dissolved chemical species through this zone by fluid convection was insignificant; and ignoring other heat losses (conductive, radiative, etc.), a heat flow of $1600 \mathrm{~mW} / \mathrm{m}^{2}$ $(0.93 \mathrm{MW})$ was required to explain the increased heat content below $175 \mathrm{~m}$ depth.

The new temperature profiles show that during the subsequent forty months (May 1987 to September 1990), temperature at lake bottom continued to rise (Fig. 5), but the average rate of increase has slowed from $0.05^{\circ} \mathrm{C} /$ month in early 1987 to $0.02^{\circ} \mathrm{C}$ /month between May 1987 and December 1989 and to $<0.01^{\circ} \mathrm{C}$ /month between December 1989 and September 1990. Both new profiles show temperature increases much farther above lake bottom than in May 1987 with increases of $>0.05^{\circ} \mathrm{C}$ up to $\sim 140 \mathrm{~m}$ depth. Subsurface cooling has extended to greater depths (to $\sim 75 \mathrm{~m}$ ). Between 75 and $140 \mathrm{~m}$ depth, temperature differences between all profiles are $\leq 0.05^{\circ} \mathrm{C}$. Although it was difficult to verify the accuracy of the thermistor to better than $0.05^{\circ} \mathrm{C}$ during field use, there have been minor changes in profile shape in this region that cannot be attributed totally to shifts in equipment calibration. The effects of heat transport within this zone are therefore discernible even if very small compared to the effects above and below this zone. The small temperature increase seen in both the new profiles up to $\sim 100 \mathrm{~m}$ depth was thus included in the heat flow calculations. The increase in hypolimnetic heat content below $100 \mathrm{~m}$ depth was 8.1 $\times 10^{9} \mathrm{kcal}$ between May 1987 and September 1990 and requires a heat flow of $0.32 \mathrm{MW}$, approximately one-third as much as before May 1987. NoJir et al. (1993) also report a lower heat flow of $0.43 \mathrm{MW}$ for the 25-month period ending December 1988. Apparently, the heat flow at lake bottom has decreased 


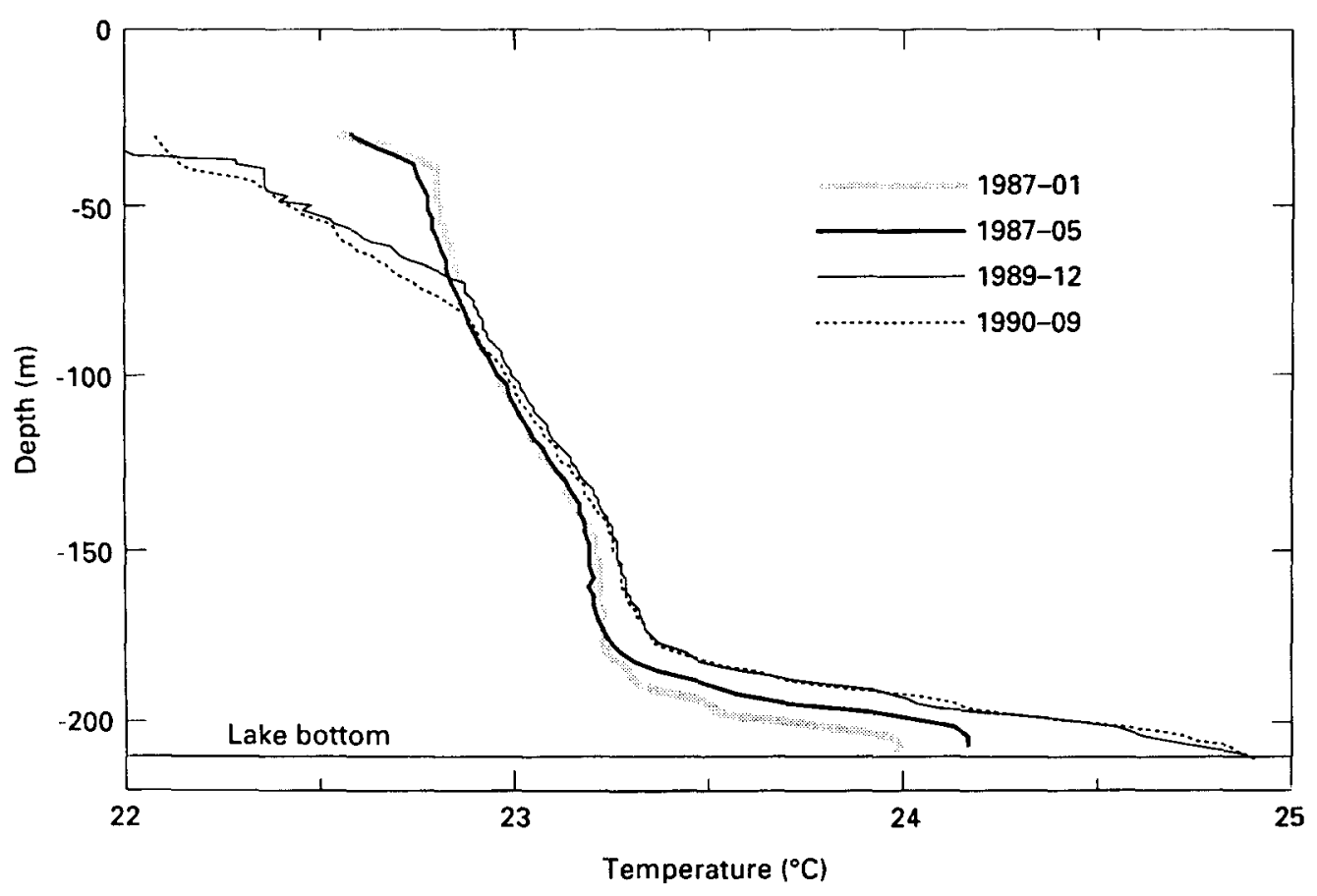

Fig. 5. Temperature vs depth. The large diurnal and seasonal variations in the surface layers $(<30 \mathrm{~m}$ depth) are not shown, but all data are available on floppy disk from the authors. The 1987 profiles are reported in KLING et al. (1989).

markedly since the period immediately following the gas burst (note that heat losses are ignored in all the heat flow calculations).

The water chemistry data (Table 1, Fig. 6) show continued dilution of surface water. Subsurface dilution due to mixing has gradually reached to $\sim 50 \mathrm{~m}$ depth (Fig. 6), not quite as deep as subsurface cooling (Fig. 5). At mid-depths (i.e. $99 \mathrm{~m}$ ) where temperature changes have been small, the water chemistry also has changed little (Table 1, Fig. 6). Apparently, chemical transport through this zone is still extremely limited. In bottom waters (i.e. $198 \mathrm{~m}$ depth), ionic strength continued to increase after May 1987, but values have levelled off showing only small changes after June 1988. Thus the water chemistry and temperature profiles have evolved in similar, but not identical, patterns. Small differences in their evolutions are expected because of the great disparity in the diffusion coefficients of heat and chemical species as discussed by TiETze (1987) and SABroux et al. (1990). Thermal perturbations will travel through the water column much faster than chemical ones. The water chemistry data have been discussed in greater detail and used to develop a hydrologic budget for the lake by TutrLe et al. (1992).

The gas probe results are shown in Table 2. In one case on each expedition, the probe was left stationary long enough for the gauge to reach a final, stable pressure. The gauge response curves (Fig. 7) match closely the shape of curves generated in laboratory tests. On the 1989 expedition, horizontal variations in gas pressure at three depths, 168, 195 and $202 \mathrm{~m}$, were found to be no greater than measurement uncertainty (Table 2), showing that total dissolved gas, like temperature and major-ion chemistry, is a function only of depth, not horizontal position. Therefore, only one station (C) was reoccupied in 1990 to test for gas pressure changes. The 1990 data show distinct gas pressure increases below $168 \mathrm{~m}$ depth during the 10-month interval (Table 2), reaching $50 \%$ of hydrostatic pressure at $206 \mathrm{~m}$ depth. In one instance, the probe was heavily weighted and allowed to sink into the sediment to test for a sharp pressure change at the sediment-water interface. The pressure measured was slightly less than in the overlying water, although it is not certain that the probe can perform accurately in the muddy sediment.

Cylinder data from selected depths are shown in Table 3. It is likely that most or all of the $\mathrm{O}_{2}$ detected is from air leakage prior to sample collecison; the high ferrous iron content of hypolimnetic water indicates strongly reducing conditions. Some of the variations in $\mathrm{Ar}$ and $\mathrm{N}_{2}$ are also caused by air leakage, but even in the most contaminated samples, the amounts of air-derived $\mathrm{CO}_{2}$ and $\mathrm{CH}_{4}$ are trivial.

The 1989 sampling provided the first opportunity to test the in-situ performance of the cylinders. Because the probe showed negligible horizontal variations in gas pressure, all cylinders filled at a given depth should contain similar gas concentrations. For two cylinders filled at $137 \mathrm{~m}$ depth, concentrations of $\mathrm{CH}_{4}$ and $\mathrm{CO}_{2}$ agree within a few percent. The same is true for a pair of cylinders from $171 \mathrm{~m}$ depth even 
Table 1. Major-ion concentrations* (in $\mathrm{mg} / \mathrm{kg}$ ) at selected depths.

\begin{tabular}{|c|c|c|c|c|c|c|c|c|}
\hline $\begin{array}{l}\text { Deptht } \\
\text { (m) }\end{array}$ & DATE $\ddagger$ & $\mathrm{Na}$ & $\mathbf{K}$ & $\mathrm{Mg}$ & $\mathrm{Ca}$ & $\mathrm{Fe}$ & $\mathrm{HCO}_{3}$ & $\mathrm{I} \S \times 10^{3}$ \\
\hline \multirow[t]{6}{*}{0} & 1986-09 & 6.4 & 3 & 16 & 14 & 1 & 165 & 3.45 \\
\hline & $1987-01$ & 6.8 & 2 & 18 & 13 & $<0.1$ & 161 & 3.62 \\
\hline & $1987-05$ & 7.3 & 3 & 19 & 16 & $<0.1$ & 163 & 3.90 \\
\hline & $1988-06$ & 6.3 & 1.8 & 9.5 & 9.2 & 0.2 & 92 & 2.16 \\
\hline & $1989-12(2)$ & 3.4 & 1.4 & 4.8 & 4.8 & 0.2 & 54 & 1.18 \\
\hline & $1990-09$ & 3 & 1 & 4 & 5 & $<0.1$ & 49 & 1.06 \\
\hline \multirow[t]{5}{*}{16} & $1987-01$ & 7 & 3 & 21 & 17 & 3.5 & 204 & 4.56 \\
\hline & $1987-05$ & 8 & 3 & 22 & 18 & 0.4 & 192 & 4.51 \\
\hline & 1988-06 & 6 & 1.9 & 12 & 11 & $<0.1$ & 107 & 2.57 \\
\hline & $1989-12$ & 3.8 & 1.4 & 5.3 & 5.3 & $<0.1$ & 54 & 1.24 \\
\hline & $1990-09$ & 3 & 1 & 5 & 6 & $<0.1$ & 57 & 1.26 \\
\hline \multirow[t]{5}{*}{99} & 1987-03 & 13 & 4 & 43 & 34 & 63 & 558 & 12.40 \\
\hline & 1987-05 & 14 & 4 & 49 & 38 & 58 & 554 & 12.90 \\
\hline & 1988-06 & 15 & 4 & 45 & 37 & 60 & 531 & 12.43 \\
\hline & $1989-12(3)$ & 14 & 4 & 45 & 35 & 59 & 536 & 12.31 \\
\hline & $1990-09$ & 14 & 4 & 44 & 35 & 60 & 532 & 12.23 \\
\hline \multirow[t]{3}{*}{171} & $1987-05$ & 18 & 5.1 & 59 & 45 & 76 & 686 & 15.90 \\
\hline & $1989-12$ & 17 & 5.1 & 55 & 45 & 83 & 694 & 15.87 \\
\hline & $1990-09$ & 16 & 5 & 54 & 42 & 76 & 693 & 15.35 \\
\hline \multirow[t]{7}{*}{198} & 1986-09 & 19 & 7 & 57 & 46 & 71 & 725 & 15.97 \\
\hline & $1987-01(4)$ & 20 & 6 & 68 & 47 & 81 & 767 & 17.64 \\
\hline & $1987-03(2)$ & 22 & 7 & 80 & 62 & 106 & 962 & 21.93 \\
\hline & $1987-05(4)$ & 24 & 7 & 85 & 65 & 96 & 963 & 22.18 \\
\hline & $1988-06$ & 25 & 7 & 90 & 71 & 110 & 1060 & 24.21 \\
\hline & $1989-12(2)$ & 24 & 6.2 & 88 & 66 & 121 & 1053 & 24.10 \\
\hline & $1990-09$ & 23 & 7 & 87 & 66 & 120 & 1039 & 23.86 \\
\hline \multirow[t]{2}{*}{206} & $1989-12(3)$ & 28 & 8 & 107 & 79 & 151 & 1253 & 29.14 \\
\hline & $1990-09$ & 27 & 8 & 100 & 77 & 140 & 1224 & 27.81 \\
\hline
\end{tabular}

* Analytical uncertainties are $\pm 5 \%$ for concentrations reported to two or more significant figures and are otherwise $\pm 1 \mathrm{mg} / \mathrm{kg}$. The $\mathrm{Fe}$ is present in divalent form and the $\mathrm{HCO}_{3}$ values represent total alkalinity. Concentrations of $\mathrm{Cl}, \mathrm{F}$ and $\mathrm{SO}_{4}$ are $\leq 1 \mathrm{mg} / \mathrm{kg}$ at all depths.

$\dagger$ Depths are from lowest point on spillway and are $\pm 1 \mathrm{~m}$ on May 1987, December 1989 and September 1990 samples when collection raft was anchored. Greater uncertainties exist on other dates due to drifting.

$\ddagger$ Analyses from September 1986 are reported in TUTTLE et al. (1987). Analyses from January 1987 , March 1987 and May 1987 are reported in KLING et al. (1989). On dates when multiple samples were collected, the number of samples is given in parentheses and the reported analyses are averages.

$\$$ Ionic strengths (I) are calculated from the reported ion concentrations.

though one of the cylinders was heavily aircontaminated. However, the two cylinders filled at $198 \mathrm{~m}$ depth differ considerably in $\mathrm{CO}_{2}$ and $\mathrm{CH}_{4}$ concentrations, 18 and $44 \%$, respectively. Three cylinders filled at $206 \mathrm{~m}$ depth (including a pair filled simultaneously) vary by $8 \%$ in $\mathrm{CO}_{2}$ and $53 \%$ in $\mathrm{CH}_{4}$ concentrations. Thus, gas loss from some of the cylinders was worse than laboratory testing had suggested.

The comparison between probe and cylinder data is made more rigorous by using the gas concentrations measured in the cylinders (Table 3) to calculate the in-situ Henry's law gas pressure for the sampled fluids. These calculated pressures are shown in Fig. 8a, where they are compared to a smooth curve drawn through the probe measurements (Table 2). With small extrapolations to the probe curve, a comparison is possible for nine cylinder samples. For seven of these, the calculated pressures deviate $<5 \%$ from the probe curve, showing that cylinder perform- ance is reasonably good in most cases. The other two cylinders have allowed significant gas loss. Subsequent laboratory testing of these two cylinders indicated that they could hold high gas pressures for many months without leakage. It was thus postulated that most gas loss problems must occur during cylinder filling, probably incomplete opening of the entry ball valve causing gas bubbles to form between it and the check valve (Fig. 3a). These bubbles would be free to escape before the cylinders could be retrieved.

For the 1990 sampling, two changes were made to improve cylinder triggering. A better trip mechanism was installed to cause fast and complete opening of the entry ball valve. Also, cylinders were triggered in an inverted position so that any bubbles formed in the ball valve would be driven by buoyancy through the check valve into the cylinder chamber. Probe and cylinder gas pressures from station $90 \mathrm{C}$ are shown in Fig. 8b. Deviations are $<5 \%$ for all seven cylinders indicating that the triggering modifications were use- 


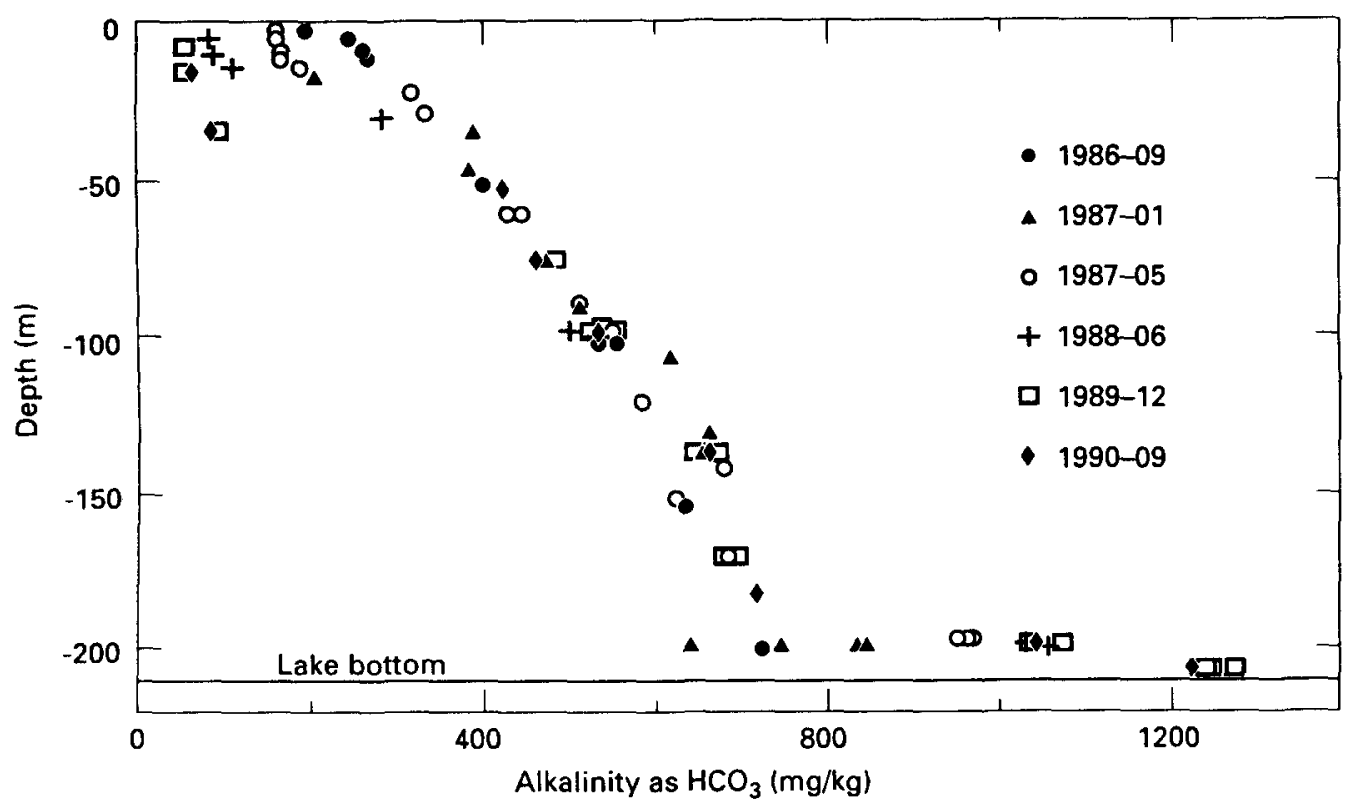

FIG. 6. Alkalinity (as $\mathrm{mg} / \mathrm{kg} \mathrm{HCO}_{3}$ ) vs depth.

ful in preventing gas loss and that the $\mathrm{CO}_{2}$ concentrations measured in these cylinders were accurate. Comparing these concentrations to earlier results provides a measurement of the $\mathrm{CO}_{2}$ recharge rate. Even though gas loss affected some of the earlier values, there are a sufficient number of data points that anomalously low values can be recognized and excluded from recharge calculations. For example, in cases where there are multiple cylinders from a given date and depth, the highest value should be the most reliable.

Table 2. Total dissolved gas pressure* measured by probe at various depths and stations.

\begin{tabular}{lccc}
\hline $\begin{array}{l}\text { Depth } \\
(\mathrm{m})\end{array}$ & Date & Station & Pressure \\
\hline 155 & $1989-12$ & B & $0.474 \pm 0.015$ \\
168 & $1989-12$ & A & $0.489 \pm 0.015$ \\
& $1989-12$ & B & $0.476 \pm 0.015$ \\
& $1990-09$ & C & $0.475 \pm 0.015$ \\
195 & $1989-12$ & A & $0.709 \pm 0.015$ \\
& $1989-12$ & B & $0.709 \pm 0.015$ \\
& $1990-09$ & C & $0.765 \pm 0.015$ \\
197 & $1989-12$ & A & $0.844 \pm 0.015$ \\
198 & $1990-09$ & C & $0.939 \pm 0.015$ \\
202 & $1989-12$ & A & $0.988 \pm 0.015$ \\
& $1989-12$ & B & $0.972 \pm 0.015$ \\
& $1989-12$ & C & $0.995 \pm 0.010$ \\
& $1990-09$ & C & $1.035 \pm 0.015$ \\
206 & $1990-09$ & C & $1.060 \pm 0.010$ \\
$211 \ddagger$ & $1990-09$ & C & $0.952 \pm ?$ \\
\hline
\end{tabular}

* In MPa absolute.

† Depths are $\pm 1 \mathrm{~m}$.

$\ddagger$ Probe buried in bottom sediment.
The $\mathrm{CO}_{2}$ concentrations obtained from all cylinders collected and analyzed to date are shown in Fig. 9. A smooth curve has been drawn through the 1990 data. At mid-depths, between 50 and $150 \mathrm{~m}$, there has been little or no change with time; most samples from previous dates plot on or near the 1990 curve. The effect of recharge is apparent below $150 \mathrm{~m}$ depth, where values in 1990 are higher than those on all previous dates. Points marked by arrows in Fig. 9 are assumed to be invalid because of improper cylinder filling (or in the case of the January 1987 point, because of accidental opening of the entry ball valve during transport back to the laboratory). Fortunately, another sample from the same depth exists in most cases so that few data are lost. The best data to compare with the 1990 curve are the May 1987 results, because a long time interval elapsed between these two dates. Also, the May 1987 sampling was

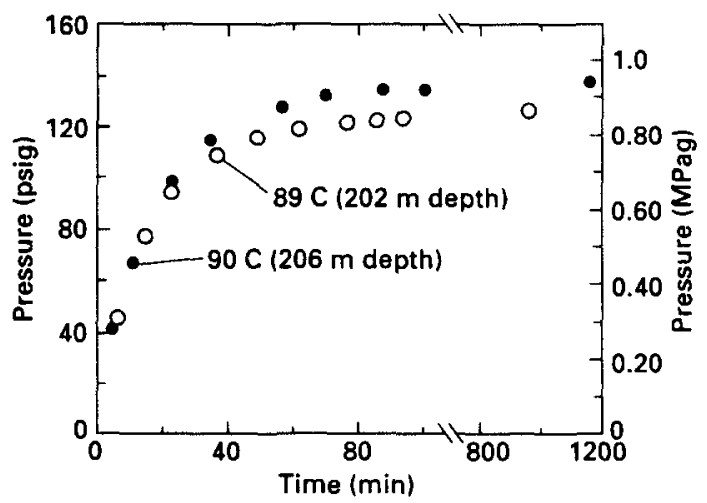

FIG. 7. Gauge pressure vs time, using gas probe at station $C$ for two runs allowed to reach final pressures. Other pressures in Table 2 were obtained by extrapolation of similar curves after $1-2 \mathrm{~h}$. 
Table 3. Dissolved-gas concentrations (in $\mu \mathrm{mol} / \mathrm{kg}$ ) and isotope compositions $\dagger$ (in $\%$ ) at selected depths

\begin{tabular}{|c|c|c|c|c|c|c|c|c|c|c|}
\hline $\begin{array}{l}\text { Depth } \\
(\mathrm{m}) \ddagger\end{array}$ & Date $\S$ & $\mathrm{He}$ & $\mathrm{Ar}$ & $\mathrm{O}_{2}$ & $\mathrm{~N}_{2}$ & $\mathrm{CH}_{4}$ & $\mathrm{CO}_{2}$ & $\delta^{13} \mathrm{C}-\mathrm{DIC}$ & $\delta^{13} \mathrm{C}-\mathrm{CH}_{4}$ & $\delta \mathrm{D}-\mathrm{CH}_{4}$ \\
\hline 76 & $\begin{array}{l}1987-01 \\
1989-12 B \\
1990-09 C\end{array}$ & $\begin{array}{l}0.55 \\
0.17 \\
0.21\end{array}$ & $\begin{array}{l}3.6 \\
4.1 \\
4.7\end{array}$ & $\begin{array}{c}<1 \\
2.7 \\
1.1\end{array}$ & $\begin{array}{l}198 \\
217 \\
211\end{array}$ & $\begin{array}{l}111 \\
249 \\
299\end{array}$ & $\begin{array}{l}70000 \\
72600 \\
72600\end{array}$ & $\begin{array}{l}-3.8 \\
-3.6 \\
-3.8\end{array}$ & $\begin{array}{l}-48.9 \\
-45.0 \\
-48.2\end{array}$ & $\begin{array}{l}-241 \\
\text { n.a. } \\
\text { n.a. }\end{array}$ \\
\hline 99 & $\begin{array}{l}1987-03 \\
1987-05 \\
1987-05 \\
1988-06 \\
1989-12 \mathrm{~A} \\
1990-09 \mathrm{C}\end{array}$ & $\begin{array}{l}0.35 \\
0.10 \\
0.13 \\
0.29 \\
0.28 \\
0.29\end{array}$ & \begin{tabular}{r|}
2.1 \\
0.7 \\
37.2 \\
8.1 \\
3.8 \\
4.8
\end{tabular} & $\begin{array}{c}1.1 \\
2.0 \\
330 \\
9.9 \\
5.6 \\
8.3\end{array}$ & $\begin{array}{c}86.7 \\
75.7 \\
3110 \\
462 \\
175 \\
246\end{array}$ & $\begin{array}{l}81.1 \\
79.1 \\
162 \\
249 \\
294 \\
309\end{array}$ & $\begin{array}{l}74900 \\
78800 \\
92300 \\
86600 \\
88500 \\
90300\end{array}$ & $\begin{array}{l}-2.9 \\
-3.2 \\
-2.9 \\
\text { n.a. } \\
-3.1 \\
-3.4\end{array}$ & $\begin{array}{l}\text { n.a. } \\
\text { n.a. } \\
\text { n.a. } \\
-43.8 \\
-45.6 \\
-50.0\end{array}$ & $\begin{array}{c}\text { n.a. } \\
\text { n.a. } \\
\text { n.a. } \\
-235 \\
\text { n.a. } \\
\text { n.a. }\end{array}$ \\
\hline 137 & $\begin{array}{l}1989-12 \mathrm{~A} \\
1989-12 \mathrm{~B} \\
1990-09 \mathrm{C}\end{array}$ & $\begin{array}{l}0.30 \\
0.41 \\
0.42\end{array}$ & $\begin{array}{l}3.2 \\
4.6 \\
3.6\end{array}$ & $\begin{array}{r}3.2 \\
13.9 \\
6.1\end{array}$ & $\begin{array}{l}158 \\
240 \\
164\end{array}$ & $\begin{array}{l}419 \\
433 \\
430\end{array}$ & $\begin{array}{l}128000 \\
136000 \\
131000\end{array}$ & $\begin{array}{l}\text { n.a. } \\
-3.0 \\
-3.2\end{array}$ & $\begin{array}{c}\text { n.a. } \\
-45.6 \\
-50.0\end{array}$ & $\begin{array}{l}\text { n.a. } \\
\text { n.a. } \\
\text { n.a. }\end{array}$ \\
\hline 171 & $\begin{array}{l}1987-05 \\
1989-12 \mathrm{~A} \\
1989-12 \mathrm{C} \\
1990-09 \mathrm{C}\end{array}$ & $\begin{array}{l}0.27 \\
0.31 \\
0.29 \\
0.54\end{array}$ & $\begin{array}{c}2.9 \\
344 \\
2.8 \\
5.1\end{array}$ & $\begin{array}{c}<0.8 \\
6670 \\
6.7 \\
24.1\end{array}$ & $\begin{array}{r}166 \\
27100 \\
177 \\
203\end{array}$ & $\begin{array}{l}272 \\
481 \\
485 \\
541\end{array}$ & $\begin{array}{l}132000 \\
134000 \\
138000 \\
146000\end{array}$ & $\begin{array}{l}-3.0 \\
-3.1 \\
\text { n.a. } \\
-3.3\end{array}$ & $\begin{array}{l}\text { n.a. } \\
\text { n.a. } \\
\text { n.a. } \\
-43.1\end{array}$ & $\begin{array}{l}\text { n.a. } \\
\text { n.a. } \\
\text { n.a. } \\
\text { n.a. }\end{array}$ \\
\hline 183 & $1990-09 \mathrm{C}$ & 0.78 & 4.1 & 10.9 & 193 & 593 & 147400 & -3.2 & -46.2 & n.a. \\
\hline 198 & $\begin{array}{l}1987-01 \\
1987-03 \\
1987-03 \\
1987-05 \\
1987-05 \\
1987-05 \\
1988-06 \\
1989-12 \mathrm{~A} \\
1989-12 \mathrm{C} \\
1990-09 \mathrm{C}\end{array}$ & $\begin{array}{l}1.1 \\
0.64 \\
1.1 \\
0.40 \\
0.86 \\
0.49 \\
0.64 \\
1.1 \\
1.7 \\
2.0\end{array}$ & $\begin{array}{r}4.5 \\
1.4 \\
2.2 \\
<1.2 \\
16.8 \\
<2.3 \\
1.3 \\
2.9 \\
3.5 \\
3.8\end{array}$ & $\begin{array}{r}2.6 \\
0.7 \\
1.1 \\
2.3 \\
21.8 \\
3.9 \\
3.8 \\
2.5 \\
13.5 \\
27.1\end{array}$ & $\begin{array}{c}146 \\
58.0 \\
159 \\
55.4 \\
1560 \\
95.5 \\
64.0 \\
101 \\
226 \\
560\end{array}$ & $\begin{array}{l}308 \\
170 \\
205 \\
154 \\
413 \\
255 \\
195 \\
492 \\
771 \\
876\end{array}$ & $\begin{array}{l}159000 \\
146000 \\
177000 \\
124000 \\
193000 \\
184000 \\
128000 \\
203000 \\
244000 \\
257000\end{array}$ & $\begin{array}{l}-3.0 \\
-3.0 \\
-3.2 \\
-3.0 \\
-3.1 \\
-3.2 \\
\text { n.a. } \\
-3.3 \\
-3.2 \\
-3.5\end{array}$ & $\begin{array}{c}-49.6 \\
\text { n.a. } \\
-46.9 \\
-51.2 \\
\text { n.a. } \\
-44.4 \\
\text { n.a. } \\
\text { n.a. } \\
-46.9 \\
-47.0\end{array}$ & $\begin{array}{c}-217 \\
\text { n.a. } \\
-246 \\
-268 \\
\text { n.a. } \\
-245 \\
\text { n.a. } \\
\text { n.a. } \\
\text { n.a. } \\
\text { n.a. }\end{array}$ \\
\hline 206 & $\begin{array}{l}1989-12 \mathrm{~A} \\
1989-12 \mathrm{~A} \\
1989-12 \mathrm{~B} \\
1990-09 \mathrm{C}\end{array}$ & $\begin{array}{l}1.6 \\
1.2 \\
1.3 \\
1.4\end{array}$ & $\begin{array}{l}1.4 \\
4.0 \\
3.5 \\
5.8\end{array}$ & $\begin{array}{r}1.4 \\
6.7 \\
11.3 \\
17.5\end{array}$ & $\begin{array}{l}150 \\
137 \\
218 \\
457\end{array}$ & $\begin{array}{r}987 \\
635 \\
1124 \\
1142\end{array}$ & $\begin{array}{l}281000 \\
259000 \\
274000 \\
293000\end{array}$ & $\begin{array}{l}-3.2 \\
-3.2 \\
-3.4 \\
-3.5\end{array}$ & $\begin{array}{c}\text { n.a. } \\
\text { n.a. } \\
-46.7 \\
-45.8\end{array}$ & $\begin{array}{l}\text { n.a. } \\
\text { n.a. } \\
\text { n.a. } \\
\text { n.a. }\end{array}$ \\
\hline 209 & $\begin{array}{l}1990-09 \mathrm{C} \\
1990-09 \mathrm{C}\end{array}$ & $\begin{array}{l}2.1 \\
1.7\end{array}$ & $\begin{array}{l}2.7 \\
2.1\end{array}$ & $\begin{array}{r}9.0 \\
14.4\end{array}$ & $\begin{array}{l}194 \\
214\end{array}$ & $\begin{array}{l}1540 \\
1730\end{array}$ & $\begin{array}{l}299000 \\
298000\end{array}$ & $\begin{array}{l}-3.6 \\
-3.4\end{array}$ & $\begin{array}{l}-45.1 \\
-45.5\end{array}$ & $\begin{array}{l}\text { n.a. } \\
\text { n.a. }\end{array}$ \\
\hline
\end{tabular}

* Analytical uncertainties are $\pm 20 \%$ for $\mathrm{He}$ and \pm the greater of $2 \%$ or $1 \mu \mathrm{mol} / \mathrm{kg}$ for the other gases.

$\dagger$ Analytical uncertainties are $\pm 0.1 \%$ for $\delta^{13} \mathrm{C}$ and $\pm 5 \%$ for $\delta \mathrm{D}$. n.a. means not analyzed.

$\ddagger$ Uncertainties are as in Table 1 .

§ Analyses from 1987-01, 1987-03, and 1987-05 are reported in KLING et al. (1989). Letters A, B and C refer to station locations.

|| Filled simultaneously.

performed from an anchored raft and included several cylinders from depths $>140 \mathrm{~m}$. Therefore, this profile, shown as a dashed line on Fig. 9, is welldefined.

\section{Recharge rates and processes}

Multiplying the increase in $\mathrm{CO}_{2}$ concentration at each depth (Fig. 9) by the appropriate volume of water (Fig. 2; hypsographic curve in KLING et al., 1989) gives the total increase in $\mathrm{CO}_{2}$ as $8.6 \times 10^{8}$ moles in forty months or $2.6 \times 10^{8} \mathrm{~mol} / \mathrm{a}$. An analogous calculation using the May 1987 and the December 1989 data results in a very similar recharge rate, $2.5 \times 10^{8} \mathrm{~mol} / \mathrm{a}$. Comparing the 1990 curve to the January and March 1987 profiles yields higher recharge rates, $3.0 \times 10^{8}$ and $2.8 \times 10^{8} \mathrm{~mol} / \mathrm{a}$, respectively, although these profiles contain only one depth below $150 \mathrm{~m}$. An even higher recharge rate, 3.2 $\times 10^{8} \mathrm{~mol} / \mathrm{a}$, is obtained by comparing the four points below $150 \mathrm{~m}$ depth in the November 1986 profile of Tietze (1987) to the 1990 curve on Fig. 9. Thus, it appears that the $\mathrm{CO}_{2}$ recharge rate was higher just after the gas burst than during the period between May 1987 and September 1990, despite the uncertainties in some of the $\mathrm{CO}_{2}$ profiles. There are also uncertainties in the bathymetry. Using the hypsographic curve of NoJiri et al. (1993) would reduce all the rates calculated above by nearly $15 \%$. After accounting for this uncertainty as well as the temporal changes, the $\mathrm{CO}_{2}$ recharge rate can still be reasonably well-constrained at $2.6 \pm 0.6 \times 10^{8} \mathrm{~mol} / \mathrm{a}$ when averaged over the first 4-a following the gas burst.

The $\mathrm{CO}_{2}$ fluxes calculated previously by NoJiRI $e t$ al. (1993) and SANo et al. (1990) are much larger than this, by factors of 4 and 8 , respectively. The discrep- 

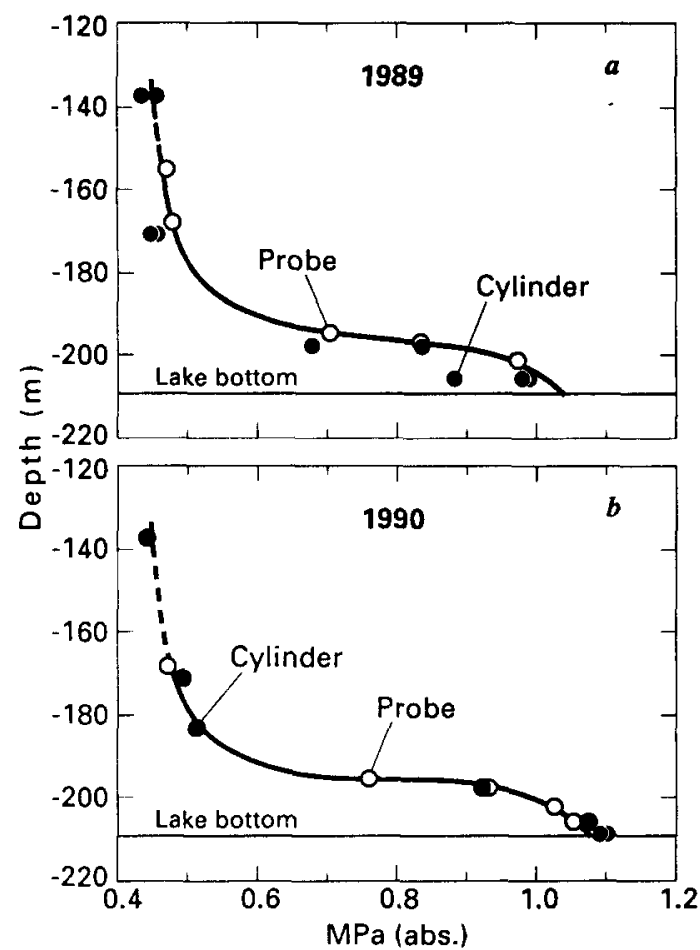

FIG. 8. In-situ gas pressures calculated from cylinder data compared to pressures measured using gas probe: (a) December 1989; (b) September 1990. The $\mathrm{CO}_{2}$ partial pressures were calculated and corrected for hydrostatic effects using solubility, partial molar volume and fugacity coefficient data from WeIss (1974). In-situ pressures for other gases were calculated from the solubility data of Wilhelm et al. (1977) assuming ideality. All $\mathrm{O}_{2}$ in cylinders was assumed to be from air contamination and was used to correct $\mathrm{N}_{2}$ and Ar values using air ratios.

ancy arises in part because these studies encompass different time intervals (November 1986-December 1988) and in part because of the assumptions made in their calculations. For example, NoIIR et al. (1993) proposed a linear extrapolation of the $\mathrm{CO}_{2}$-TDS relation from $190 \mathrm{~m}$ depth to lake bottom $(210 \mathrm{~m})$ where the water would be near saturation in $\mathrm{CO}_{2}$. However, the $\mathrm{CO}_{2}$ concentrations measured in 1990 just $1 \mathrm{~m}$ above bottom (Table 3 ) were less than half the calculated saturation concentration of 630,000 $\mu \mathrm{mol} / \mathrm{kg}$ at $25^{\circ} \mathrm{C}$ (solubility and fugacity data of WeIss, 1974). The relation between $\mathrm{CO}_{2}$ and dissolved solids is clearly more complex than previously thought. The data presented here show that, at $198 \mathrm{~m}$ depth, ionic strength has remained fairly stable since June 1988 (Table 1), while $\mathrm{CO}_{2}$ concentrations have continued to increase (Table 3, Fig. 9). This behavior is not likely to be due to mixing of water from a deeper layer because both $\mathrm{CO}_{2}$ and ionic strength should increase in this process. For the same reason, it is not likely to be due to diffusive transport of $\mathrm{CO}_{2}$ from a deeper layer or double diffusive convection within the water column, the diffusion coefficients of $\mathrm{CO}_{2}$ and most common ions being nearly equal (JosT, 1960). Further, similar behavior has occurred at 206 m depth, where $\mathrm{CO}_{2}$ concentrations increased between the 1989 and 1990 samplings while major-ion concentrations either remained the same or even decreased slightly (Tables 1 and 3). That $\mathrm{CO}_{2}$ and major-ion concentrations do not covary shows that no unique relation can exist between $\mathrm{CO}_{2}$ and ionic strength (or TDS) in the bottom $20 \mathrm{~m}$ of the water column. Nevertheless, the proposal by NoJIRI $e t$ al. (1993) of $\mathrm{CO}_{2}$ saturation at lake bottom could certainly apply to the pure recharge fluid entering the lake. This has been suggested by KuSAKaBE and SANO (1991) and raises the possibility that the recharge fluid could contain free $\mathrm{CO}_{2}$ gas, which would have important consequences for the development of water-column structure.

If the incoming recharge fluid contains free $\mathrm{CO}_{2}$, bubbles of gas could separate from the liquid phase as it enters the lake and dissolve in the overlying water layers. Gas-phase separation could thus help explain the differing evolutions of the $\mathrm{CO}_{2}$ and major-ion concentrations near lake bottom. However, an enormous volume flow of $\mathrm{CO}_{2}$ gas, approximately $200 \mathrm{l} / \mathrm{s}$ (at STP; $10 \mathrm{l} / \mathrm{s}$ at lake-bottom pressure), would be required to account for the entire $\mathrm{CO}_{2}$ recharge observed (Fig. 9). Other observations suggest that gaseous $\mathrm{CO}_{2}$ can make up only a small fraction of the total $\mathrm{CO}_{2}$ recharge. First, because there has been little or no increase in $\mathrm{CO}_{2}$ concentrations above 150 $m$ depth (Fig. 9), rising bubbles must dissolve within $60 \mathrm{~m}$ of the bottom. Experimental work on rates of bubble collapse (WISE and Houghton, 1966) suggests that this is possible only if bubble diameters are no greater than 5-10 $\mathrm{mm}$. Larger bubbles would rise to the lake surface, a process not reported at Lake Nyos. Second, horizontal variations in gas pressure and water chemistry are small even a few meters above the bottom (Tables 1 and 2). Vents of gas bubbles would be expected to disrupt the horizontal layers, and if present, must be either too weak or too widespread to generate a large, distinct plume. Vents of thermal water high in dissolved $\mathrm{CO}_{2}$ but without abundant gas bubbles would be less likely to form a plume and better able to set up the layer structure observed in the water column. Studies of the East African Lake Kivu (Tietze, 1978; Tietze $e t$ al., 1980), a giant analog of Lake Nyos, showed that such homogenous layers can be tens of kilometers in extent, apparently formed in response to localized inputs of thermal water. A third line of evidence is the gas composition data (Table 3 ). Strong streams of $\mathrm{CO}_{2}$ bubbles would strip the less-soluble gases such as $\mathrm{CH}_{4}, \mathrm{Ar}, \mathrm{N}_{2}$ and $\mathrm{He}$ from the deeper layers over time, but no obvious depletions have occurred. Concentrations of $\mathrm{CH}_{4}$ have in fact increased.

If it is assumed that the $\mathrm{CO}_{2}$ is entirely dissolved in the recharge fluid, the $\mathrm{CO}_{2}$ recharge rate can be used to calculate a range of water flow rates and temperatures. The minimum $\mathrm{CO}_{2}$ concentration in the incoming fluid is apparently $0.30 \mathrm{~mol} / \mathrm{kg}$, the highest measured value at $209 \mathrm{~m}$ depth (Table 3 ). $\mathrm{A} \mathrm{CO}_{2}$ flux 


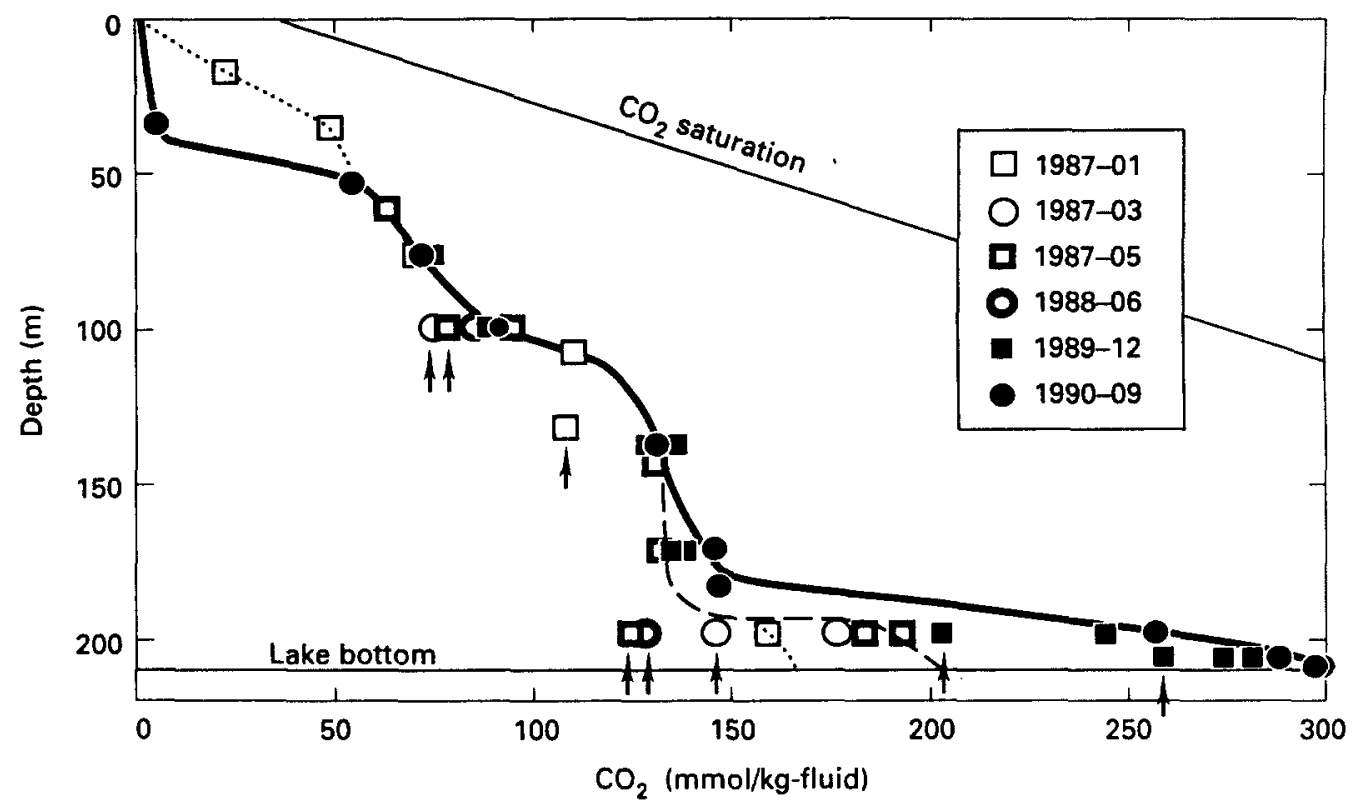

Fig. 9. Concentration of $\mathrm{CO}_{2}$ in cylinder samples from all dates and depths. The recharge rate is calculated by comparing the September 1990 curve (solid line) to the May 1987 curve (dashed line) or the January 1987 curve (dotted line) at depths below $150 \mathrm{~m}$. Points marked by arrows are presumed to be low due to cylinder failure (see text) and are not used in the recharge rate calculations. Surface loss of $\mathrm{CO}_{2}$ is shown by the profile evolution between 0 and $50 \mathrm{~m}$ depth. Field measurements of $\mathrm{pH}$ and alkalinity have helped define the profiles in this region of lower $\mathrm{pCO}_{2}$ values. The " $\mathrm{CO}_{2}$-saturation" line represents the maximum possible concentration of $\mathrm{CO}_{2}$ in solution as a function of total pressure, $89 \mathrm{kPa}$ atmospheric $+9.76 \mathrm{kPa} / \mathrm{m}$ depth.

of $2.6 \times 10^{8} \mathrm{~mol} / \mathrm{a}$ would then require an input of $8.7 \times 10^{5} \mathrm{~m}^{3} / \mathrm{a}(27 \mathrm{l} / \mathrm{s})$ of water. If the increase in heat content below $100 \mathrm{~m}$ depth $\left(8.1 \times 10^{9} \mathrm{kcal}\right.$ between May 1987 and September 1990) were due entirely to transport by the recharge water, the water temperature would be $26.1^{\circ} \mathrm{C}$, slightly warmer than the $24.9^{\circ} \mathrm{C}$ actually measured at $209 \mathrm{~m}$ depth (Fig. 5). Repeating the calculations for a recharge fluid that is $\mathrm{CO}_{2}$ saturated at the lake-bottom pressure of 2.1 $\mathrm{MPa}(21 \mathrm{~atm})$ yields a temperature of $28.6^{\circ} \mathrm{C}, \mathrm{a} \mathrm{CO}_{2}$ concentration of $0.57 \mathrm{~mol} / \mathrm{kg}$ and a flow rate of $4.7 \times$ $10^{5} \mathrm{~m}^{3} / \mathrm{a}(15 \mathrm{l} / \mathrm{s})$. These ranges of temperature and flow rates are close to the $30.4^{\circ} \mathrm{C}$ and $13 \mathrm{l} / \mathrm{s}$ values calculated by NoJiRI et al. (1993) based on the assumption that the recharge fluid is saturated with amorphous silica. The agreement is very good given the difference in the two approaches. Recharge is thus a low-temperature process, more consistent with the existence of a low-temperature source of $\mathrm{CO}_{2}$ than a near-surface magma chamber or hightemperature hydrothermal system.

The range of temperatures and flow rates could be larger if a significant fraction of the $\mathrm{CO}_{2}$ recharge consists of free gas. The heat of solution of $\mathrm{CO}_{2}$ gas in water is considerable $(-4.7 \mathrm{kcal} / \mathrm{mol})$ while the heat capacity is only $9.1 \mathrm{cal} / \mathrm{mol}^{\circ} \mathrm{C}$. When $\mathrm{CO}_{2}$ dissolves in water, there is a rise in water temperature that is mainly due to the heat of solution, even if the $\mathrm{CO}_{2}$ is initially much hotter than the water or performs expansion work. If the recharge fluid contains free $\mathrm{CO}_{2}$, part of the hypolimnetic heat increase would derive from the heat of solution and part from fluid transport. In the extreme case, where it is assumed that all the $\mathrm{CO}_{2}$ recharge consists of free gas, the increase in hypolimnetic heat content due to the heat of solution would be $4.0 \times 10^{9} \mathrm{kcal}$, about half the increase actually measured. Required recharge fluid temperatures would then be $1-2^{\circ} \mathrm{C}$ cooler assuming the same range of flow rates as calculated above.

There may be important temporal variations in recharge temperatures and flow rates as well. The ranges reported here are average values for the period between May 1987 and September 1990. They mainly serve to show that recharge temperatures are low and do not imply that the recharge fluid has a fixed composition. In fact, a fixed recharge-fluid composition is difficult to reconcile with the behavior of the major-ion chemistry in bottom waters. As noted previously, increases in $\mathrm{CO}_{2}$ concentration (Table 3) are no longer accompanied by increases in ionic strength (Table 1). The data from $198 \mathrm{~m}$ depth, displayed in Fig. 10, suggest that between the May 1987 and June 1988 samplings, the rapid influx of ionic species into bottom waters ceased. The cessation may not have been as abrupt as implied in Fig. 10, but it appears to have occurred during the same time interval as the drop in the rate of $\mathrm{CO}_{2}$ recharge and to require a change in recharge-fluid composition rather than simply a change in flow rate.

In a simple 2-component mixing model where the recharge fluid continually vents into the more-dilute hypolimnetic water, concentrations of $\mathrm{CO}_{2}$ and ionic 


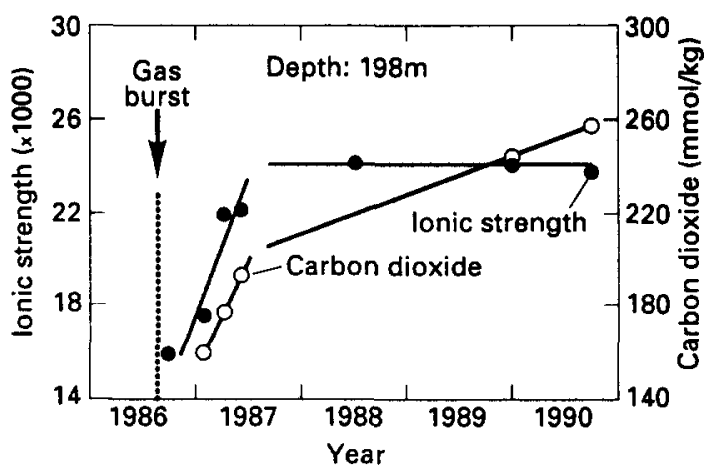

FIG. 10. The evolution of $\mathrm{CO}_{2}$ and ionic strength with time at $198 \mathrm{~m}$ depth. Concentrations of $\mathrm{CO}_{2}$ are taken from Table 3 assuming that the highest value on each date is the most reliable (see text). The cylinder from June 1988 is assumed to have lost $\mathrm{CO}_{2}$ based on Fig. 9.

species in the hypolimnion would be expected to increase after the gas burst but then level off as some steady-state conditions were reached between inputs and transport through the water column. However, the approach to steady-state should be gradual, rather than sudden as has been the case with ionic strength (Fig. 10). Also, the concentrations of all chemical species including $\mathrm{CO}_{2}$ should completely level off at the same time, even if recharge fluid flow rate is variable. After June $1988, \mathrm{CO}_{2}$ recharge continued at a reduced but easily measurable rate, while modifications in water chemistry have become restricted to changes in the relative proportions of the various ions and possibly, slight decreases in ionic strength (Table 1). Mineral saturation could play an important role in controlling certain ion concentrations; for example, authigenic siderite has been reported in the lake sediments (BERNARD and SyMONDS, 1989). However, the abrupt flattening in the ionic strength trend (Fig. 10) was certainly not caused entirely by mineral saturation. Bottom waters remain undersaturated with respect to calcite (TuTTLE et al., 1992), and yet $\mathrm{Ca}$ as well as $\mathrm{Na}$ and $\mathrm{Mg}$ concentrations level off or drop slightly after June 1988. Given the topographic relief around Lake Nyos (Fig. 2), the mixing model should contain a third component; that is, a dilute meteoric fluid flowing into the lake bottom from the granitic crater walls as suggested by TurrLe et al. (1992). A sudden increase in the flow rate of this dilute fluid, or decrease in the flow rate of the recharge fluid, could cause rate changes similar to those in Fig. 10. However, between May 1987 and June 1988, there were no reports of large earthquakes or sudden changes in lake level that could significantly affect groundwater flow in the area. In addition, the relative flow rates of the recharge fluid and the meteoric fluid after June 1988 would have to balance in such a way as to cause only small changes in major-ion concentrations in bottom waters.

It is difficult to account for a change in the composition of the recharge fluid, which is similar in many respects to soda-spring type fluids. Soda springs result when groundwater contacts a potent source of $\mathrm{CO}_{2}$ and the acidic solution chemically attacks the surrounding rock to become mineralized. Many such springs are known to exist in Cameroon (MARECHAL, 1976), and in general, soda springs are stable features than can persist for millennia (see e.g. BARnes et al., 1984). The most-probable scenario is that the recharge fluid is mainly hypolimnetic water involved in a sub-bottom convection system: sinking down through bottom sediments; acquiring $\mathrm{CO}_{2}$, heat, and ionic species within the underlying diatreme; then rising up through faults or fractures to vent back into the lake. During the gas burst when dilution of the hypolimnion occurred, this sub-bottom convection system, labeled path A in Fig. 11, would still contain pre-burst hypolimnetic water. As long as this moreconcentrated water continued to vent, it caused the rapid increases in bottom-water ionic strength and $\mathrm{CO}_{2}$ concentration observed through May 1987 (Fig. 10). By June 1988, the water in the convection system had been replaced by more-dilute, post-burst hypolimnetic water (that is, post-burst water had completed one cycle along path $\mathrm{A}$ in Fig. 11), and increases in ionic strength tailed off and became undetectable. Circulating water continued to transport $\mathrm{CO}_{2}$ into the lake, but at a reduced rate, similar to the $2.6 \times 10^{8} \mathrm{~mol} / \mathrm{a}$ calculated above from the May 1987 and September 1990 data. This presumably represents the actual supply rate of $\mathrm{CO}_{2}$ within the diatreme.

The diatreme is thought to contain rocks similar to those found in the ejecta, including alkali basalt and ultramafic xenoliths (described by SCHENKER and Dietrich, 1986; Lockwood and Rubin, 1989). Weathering of the mafic minerals in these rocks by the recharge fluid is responsible for the unusual major-ion chemistry in bottom waters (TUTTLE $e t$ al., 1992) and some $\mathrm{CO}_{2}$ is no doubt extracted from the rocks during the weathering process. However, the release of $2.6 \times 10^{8} \mathrm{~mol} / \mathrm{a}$ of $\mathrm{CO}_{2}$ entirely by weathering should be accompanied by a major release of ionic species into the recharge fluid. The stable major-ion concentrations after June 1988 (Fig. 10; Table 1) show that there is little net transport of ionic species by the recharge fluid as it cycles through the closed loop and that weathering is a slow process compared to the rate of $\mathrm{CO}_{2}$ transport. Thus, the recharge fluid must encounter a pocket of free $\mathrm{CO}_{2}$ during the closed-loop cycle. This $\mathrm{CO}_{2}$ reservoir must extend to very shallow levels within the diatreme given that the closed-loop water-circulation time is only $\sim 1$ a, as shown by the time required to flush the moreconcentrated pre-burst water out of the loop (Fig. 10). The reservoir could contain the $\mathrm{CO}_{2}$ as liquid, a high-pressure gas, or a supercritical fluid depending on P-T conditions (KuSAKABE and SANo, 1991; NoJIRI et al., 1993). Such reservoirs are known and can be large. A reservoir of fluid $\mathrm{CO}_{2}$ near a Recent Australian maar has been drilled to produce $\mathrm{CO}_{2}$ 


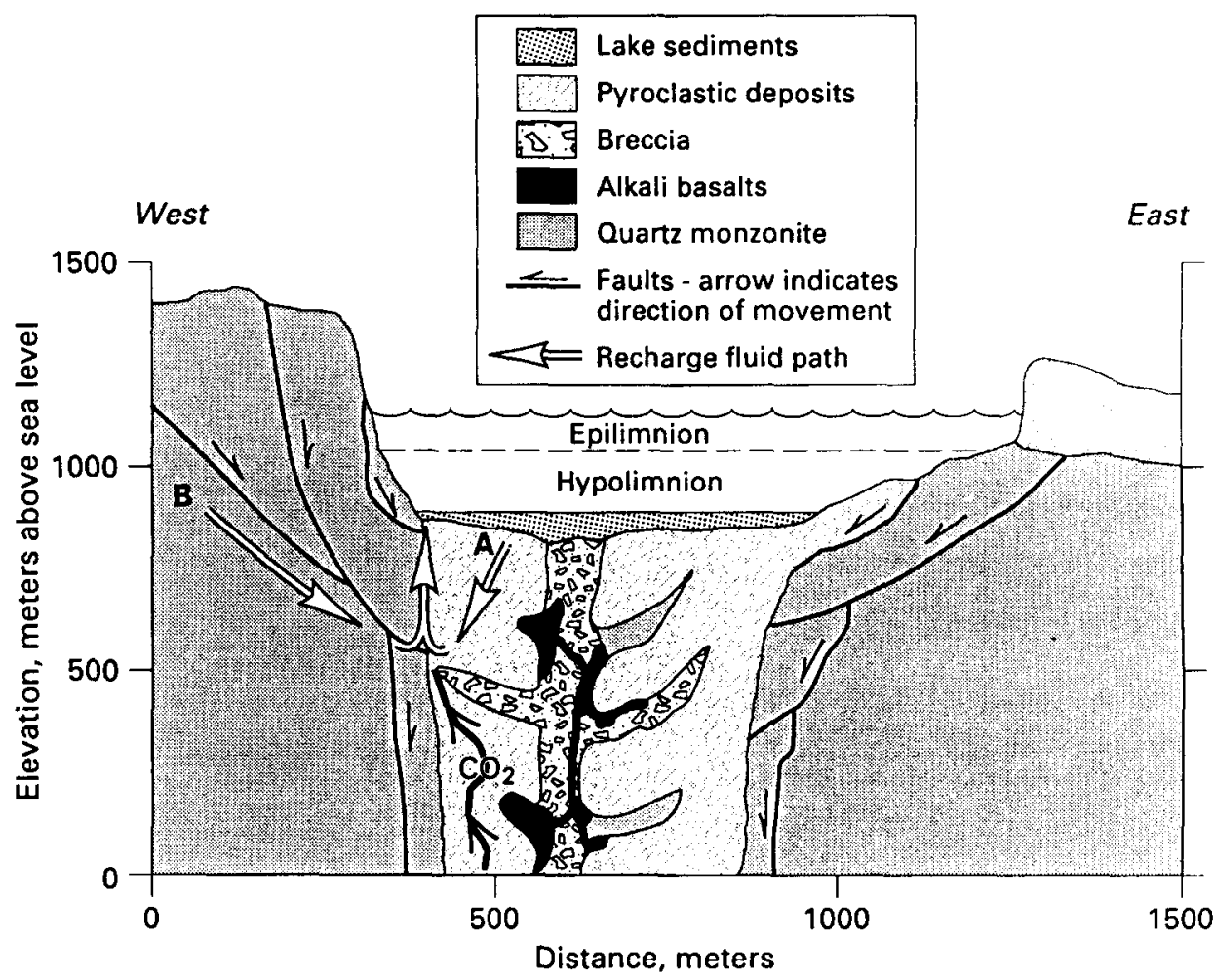

FIG. 11. Cross-section of Lake Nyos and the underlying diatreme (modified from TuTTLE et al. 1987). Hypothetical recharge fluid flow paths are shown as " $A$ " for closed-loop and " $B$ " for external source. Reservoir containing free $\mathrm{CO}_{2}$ extends up to the zone of contact with groundwater.

commercially at a rate of $6.3 \times 10^{8} \mathrm{~mol} / \mathrm{a}$ (ChIVAs $e t$ al., 1987), more than double the recharge rate at Lake Nyos.

A similar cycling of lake water has been proposed for the crater lake in the active Poas volcano, Costa Rica, where sub-bottom convection is driven by magmatic heat (Rowe et al, , 1990). At Lake Nyos, heat is probably only part of the driving force behind convection given that in bottom water, the slowly rising temperatures (Fig. 5) do not offset the density increases caused by the rising concentrations of dissolved $\mathrm{CO}_{2}$ (Fig. 10). Additional force could be provided by buoyancy. If the $\mathrm{CO}_{2}$ rapidly enters the water at the bottom of path A (Fig. 11), the density of the water would be greatly reduced and remain so until the $\mathrm{CO}_{2}$ completely dissolved. During this time, buoyant ascent of the fluid could provide considerable driving force for convective motion. As noted earlier, complete dissolution of the $\mathrm{CO}_{2}$ is likely to occur by the time the recharge fluid vents into the lake, and any residual gas bubbles must dissolve within the lower $60 \mathrm{~m}$ of the water column.

Additional samples and more-complete chemistry profiles would help test this closed-loop hypothesis as well as the constancy of the $\mathrm{CO}_{2}$-supply rate. Some additional evidence of a closed-loop system is given by the bottom-water Ar values (Table 3 ). The concentrations of this inert atmospheric gas in the local meteoric water or in groundwater directly derived from local meteoric water should be $11-13 \mu \mathrm{mol} / \mathrm{kg}$ (solubility data of WILHELM et al., 1977), and values in this range are found in the hypolimnia of other stratified crater lakes in Cameroon (KLING et al., 1991). The Ar concentrations in Lake Nyos are much lower because of losses during the 1986 gas burst but would be expected to increase with time in the deepest layers if the recharge fluid were primarily from a source external to the lake (e.g. path B in Fig. 11).

\section{Gas burst recurrence}

As hypolimnetic $\mathrm{CO}_{2}$ concentrations rise, the danger of another gas burst increases, but it is difficult to establish a precise relation between recharge rate and the probability of a gas burst. If $\mathrm{CO}_{2}$ recharge were to remain constant at $2.6 \times 10^{8} \mathrm{~mol} / \mathrm{a}$, it would require $\sim 160$ a to saturate Lake Nyos given the present-day $\mathrm{CO}_{2}$ concentrations (Fig. 9) and assuming the development of a unique mixing and stratification pattern allowing $\mathrm{CO}_{2}$ concentrations to just equal saturation at every depth. As the stratification pattern of the lake continues to evolve, the depth of seasonal mixing will determine the shallowest level at which gas build-up can occur. To date, some mixing has been observed down to $50 \mathrm{~m}$ depth (Fig. 6). If this is where a stable chemocline develops, 
the time required to saturate the lake below this level should be $\sim 140$ a, again assuming a constant recharge rate. In a simplistic model of the gas-burst process where dissolved $\mathrm{CO}_{2}$ slowly builds up to saturation pressure and is suddenly released, this 140-a period would represent the recurrence interval. However, there is no proof as yet that complete saturation of the hypolimnion can ever occur, and certainly it is not required before a gas burst. Regardless of recharge rates, another gas burst could occur any time there is sufficient mechanical input, such as a landslide, to move a large parcel of bottom water into shallower levels where dissolved gas pressure exceeds total pressure. Bubble formation would then greatly reduce fluid density, and buoyancy forces would render additional mechanical input unnecessary. The condition required for a gas burst to ensue is that depressurization of adjacent water be sufficient to sustain circulation, causing degassing of a significant fraction of the hypolimnion (see discussion by KANARI, 1989). Currently (as of 1990), water at $209 \mathrm{~m}$ depth, with a dissolved gas pressure of $1.1 \mathrm{MPa}$ (11 atm) (Fig. 8b), would have to rise to depths of $<110$ $\mathrm{m}$ for bubble formation to begin. Assuming a closedloop recharge system, $\mathrm{CO}_{2}$ concentrations in the recharge fluid will probably increase as a function of time (i.e. $\mathrm{CO}_{2}$ is incrementally added to the fluid as it circulates through the diatreme). In this case, the very deepest layers in the water column are likely to saturate well before the mid-depths, with there being no net influx of water into the lake bottom to force overlying water layers upward. Before additional constraints can be placed on a theoretical recurrence interval, factors other than $\mathrm{CO}_{2}$ recharge rate must be considered, a few of which are discussed here.

Vertical mixing is extremely limited given the large density gradient in Lake Nyos, but increasing temperatures in bottom water (Fig. 5) work to lessen the density gradient. A fluid with bottom-water composition (e.g. at $206 \mathrm{~m}$ depth, Tables 1 and 3) would need to reach $36^{\circ} \mathrm{C}$ to become less dense than $22^{\circ} \mathrm{C}$ surface water. This is above the calculated range of recharge fluid temperatures and well above present bottom-water temperatures, which appear to be leveling off near $25^{\circ} \mathrm{C}$. Thus it is unlikely that temperature alone will upset the density stratification. However, increased temperatures have a large effect on dissolved gases, reducing the solubility of $\mathrm{CO}_{2}$ by $\sim 2.5 \% /{ }^{\circ} \mathrm{C}$. By weakening the density stratification and by decreasing the $\mathrm{CO}_{2}$ storage capacity, higher bottom-water temperatures increase the danger of a gas burst recurrence.

There are surface losses of $\mathrm{CO}_{2}$, as shown in Fig. 9. Between January 1987 and September 1990, an estimated $1.3 \times 10^{9}$ moles of $\mathrm{CO}_{2}\left(3.5 \times 10^{8} \mathrm{~mol} / \mathrm{a}\right)$ were gradually lost from the surface layers. This is greater than the amount gained by bottom layers and so despite continuous recharge, Lake Nyos contains less gas at present than soon after the 1986 burst. This high surface flux is not likely to represent a long-term rate but is a consequence of the unusual lake structure following the 1986 partial mixing $\left(p \mathrm{CO}_{2}\right.$ in surface waters much higher than in the atmosphere). As the chemocline becomes more pronounced, the loss of $\mathrm{CO}_{2}$ from the lake surface should decrease due to the small transport rate across this interface. However, unless the transport rate across the chemocline becomes trivial compared to the recharge rate, the effect of surface losses will be to slow the rate of gas build-up in the hypolimnion and increase the recurrence interval.

In terms of concentration, gases other than $\mathrm{CO}_{2}$ make up $<1 \%$ of the total dissolved gas (Table 3 ; aircorrected), but because of lower solubilities, $\mathrm{N}_{2}$ and $\mathrm{CH}_{4}$ add noticeably to the total gas pressure. At 209 $\mathrm{m}$ depth they currently contribute $0.14 \mathrm{MPa}$ or $13 \%$ of the total gas pressure of $1.1 \mathrm{MPa}$ (calculated from Table 3, Fig. 8). If water from $209 \mathrm{~m}$ depth were depressurized in a Rayleigh process, the first small bubbles would be $\sim 87 \% \mathrm{CO}_{2}, 13 \% \mathrm{~N}_{2}$ and $\mathrm{CH}_{4}$, in proportion to their respective pressures. The gas phase would get progressively richer in $\mathrm{CO}_{2}$ until, at complete depressurization, it would be $\sim 99 \% \mathrm{CO}_{2}$, $1 \% \mathrm{~N}_{2}$ and $\mathrm{CH}_{4}$, in proportion to initial concentrations in solution. Although rapid degassing might only approximate a Rayleigh process, $\mathrm{N}_{2}$ and $\mathrm{CH}_{4}$ could be instrumental in initiating a gas burst but make up a trivial proportion of the gas released. The effect of these gases will be to lower the amount of $\mathrm{CO}_{2}$ that the hypolimnion can store and to increase the danger of recurrence.

It is alarming that bottom-water $\mathrm{CH}_{4}$ concentrations are increasing at a faster rate than $\mathrm{CO}_{2}$ concentrations (Table 3). Much of the $\mathrm{CH}_{4}$ increase results from biogenic production. This is evident because $\mathrm{CH}_{4}$ concentrations have also increased at mid-depths, well above the bottom $40-60 \mathrm{~m}$ of the water column where recharge effects on water chemistry, temperature, and $\mathrm{CO}_{2}$ are seen (Figs 5, 9; Table 1). Also, one ${ }^{14} \mathrm{C}$ analysis has been completed. The $\mathrm{CH}_{4}$ in sample 12-89B from $206 \mathrm{~m}$ depth (Table 3) contained $41 \%$ modern $C$, probably resulting from bacterial fermentation of sinking organic matter. The percentage of the $\mathrm{CH}_{4}$ that is biologically produced is certainly higher than this. Any $\mathrm{CH}_{4}$ produced by bacterial $\mathrm{CO}_{2}$ reduction, for example, would contain only the $1-2 \%$ modern C present in the DIC (TuTtLE et al., 1987). Note also that the $\delta^{13} \mathrm{C}$ values of the $\mathrm{CH}_{4}$ show no trends with depth or time (Table 3 ). Either the biological processes produce $\mathrm{CH}_{4}$ that is isotopically similar to that brought in by the recharge fluid or the recharge fluid does not introduce signifcant amounts of $\mathrm{CH}_{4}$. The $\delta^{13} \mathrm{C}$ values are heavy for biogenic $\mathrm{CH}_{4}$ (cf. WhITICAR et al., 1986), but similar values have been reported for Lake Kivu (DEUSER et $a l ., 1973$ ) and Lake Monoun (Evans et al., 1989). If $\mathrm{CH}_{4}$ concentrations continue to increase at present rates, they could soon have a large effect on total gas pressure in the hypolimnion. It is possible, however, that biogenic $\mathrm{CH}_{4}$ production has been enhanced by 
nutrient redistribution during the gas burst as has been suggested for Lake Monoun (Evans et al., 1989). If this is the case, methanogenesis may decrease with time.

\section{CONCLUSIONS}

Using anchored sampling stations and a new gas probe, it has been shown that horizontal variations in $\mathrm{CO}_{2}$ concentrations, like those in temperature and water chemistry, are small in the bottom waters of Lake Nyos. The rate of horizontal mixing must be very rapid compared to the rate of vertical mixing, and profiles at a single site can therefore be used to calculate fluxes for the entire central basin. The $\mathrm{CO}_{2}$ recharge rate of $2.6 \times 10^{8} \mathrm{~mol} / \mathrm{a}$ is much smaller than previous estimates (SANo et al., 1990; NoJIRI et al., 1993) but may better represent the long-term rate of supply from the underlying diatreme. It is certainly large enough to support the hypothesis that longterm build up of $\mathrm{CO}_{2}$ in the stratified hypolimnion can occur, a critical part of the limnological theory of the gas burst. The resulting 140 -a period required to achieve saturation in the hypolimnion favors the possibility that previous gas bursts have occurred at Lake Nyos even though the age of the crater may be only 400-500 a (Lockwood and RuBIN, 1989). However, it is only a crude estimate of the recurrence interval.

The $\mathrm{CO}_{2}$ recharge rate is of immediate value in plans to artificially pipe the gas out of bottom waters (Halbwachs et al., 1990). The piping rate should at least equal the recharge rate to be effective in preventing gas accumulation. However, the rapid horizontal mixing should allow the entire bottom area to be degassed by pipes installed in one location. Proposed remedial actions also include lowering lake surface level $40 \mathrm{~m}$ to the base of the natural spillway, which is structurally weak and could fail causing massive flooding (Lockwood et al., 1988; ScHUSTER and Lockwoop, 1991). Hydrostatic pressures would be reduced by $0.4 \mathrm{MPa}$ in this process; meaning that, should the dam fail prior to the proposed gas removal process, dissolved $\mathrm{CO}_{2}$ pressures would be closer to saturation values. This can be visualized by lowering the " $\mathrm{CO}_{2}$ saturation" line $40 \mathrm{~m}$ on Fig. 9. At no point on the 1990 profile would $\mathrm{CO}_{2}$ concentrations be saturated, but a small disturbance of the water column could more easily initiate a gas burst. Also, a gas eruption could begin beneath the lake floor if pressure is reduced by either dam failure or intentional lake drainage (see TIETzE, 1987). This is especially a threat if a $\mathrm{CO}_{2}$ reservoir exists only a short distance below lake bottom as suggested by the closed-loop recharge model, and the danger would remain even after completion of gas removal from the hypolimnion. On the other hand, if the $\mathrm{CO}_{2}$ reservoir does extend to shallow depths, it may be possible to drill into the reservoir and release the trapped gas directly to the atmosphere, by bypassing the existing recharge system. If successful, this procedure (discussed by Schenker and Dietrich 1986) could eliminate the problem of gas buildup in the hypolimnion as well as the danger in lowering the lake level. Exploratory drilling should be attempted as part of the hazards reduction plan.

Acknowledgements-The authors thank those who have performed various aspects of the fieldwork ( $\mathrm{J}$. Lockwood, H. Sigurdsson, J. Devine, S. Tebor) and laboratory analyses (M. Huebner, C. Prien, P. Briggs). J. Kennelly, $W$. Wendt and $F$. Grubb provided the calibrated thermistor equipment. M. Ohms and L. Evans helped construct the gas probe. C. Janik, L. Miller, M. Kusakabe, K. Tietze, A. Lachenbruch and D. Sheppard provided useful comments on the manuscript. Methane sample was dated at the NSF Accelerator Facility at the University of Arizona and was partially funded by NSF grant EAR85-12761. Fieldwork was financed by a grant from the National Geographic Society and by NSF grants 8709978 to G. W. K. and 8400532 and 8544206 to D. A. Livingstone. Substantial support was also provided by the U.S. Embassy and U.S. AID Mission in Yaounde, Cameroon.

Editorial handling: Brian Hitchon.

\section{REFERENCES}

Barberi F., Chelini W., Marinelli G. and Martini M (1989) The gas cloud of Lake Nyos (Cameroon, 1986): results of the Italian technical mission. J. Volc. Geotherm. Res. 39, 125-134.

Barnes I., IRWIN W. P. and White D. E. (1984) Map showing distribution of carbon-dioxide springs and major zones of seismicity. U.S. Geol. Surv. Misc. Invest. Ser. Map I-1528 (with text).

Bernard A. and Symonds R. B. (1989) The significance of siderite in the sediments from Lake Nyos, Cameroon. J. Volc. Geotherm. Res. 39, 187-194.

Chivas A. R., Barnes I., Evans W. C., Lupton J. E. and StONE J. O. (1987) Liquid carbon dioxide of magmatic origin and its role in volcanic eruptions. Nature 326, 587589.

Deuser W. G., Degens E. T., Harvey G. R. and Rubin M. (1973) Methane in Lake Kivu: new data bearing on its origin. Science 181, 51-53.

Enns T., Scholander P. F. and Bradstreet E. D. (1965) Effect of hydrostatic pressure on gases dissolved in water. J. phys. Chem. 69, 389-391.

Evans W. C., Robinson S., White L. D., KLing G. and TutTle M. (1989) Isotopic studies of Lakes Nyos and Monoun, Cameroon. Trans. Am. Geophys. Un. 70, 1377.

Evans W. C., White L. D. and RapP J. B. (1988) Geochemistry of some gases in hydrothermal fluids from the southern Juan de Fuca Ridge. J. geophys. Res. 93, 15, $305-15,313$.

Freeth S. J. and Kay R. L. F. (1987) The Lake Nyos gas disaster. Nature 325, 104-105.

GiggenbaCH W. F. (1990) Water and gas chemistry of Lake Nyos and its bearing on the eruptive process. J. Volc. Geotherm. Res. 42, 337-362.

Halbwachs M., Vandemeulebrouck J., Sabroux J. C. and NAAH E. (1990) Artificial priming of gas-lift on Lakes Nyos and Monoun and its application to $\mathrm{CO}_{2}$ release prevention. 15th Colloquium on African Geology (abstr.), Université Nancy. 
Jost W. (1960) Diffusion in Solids, Liquids, and Gases. Academic Press.

KANARI S. (1989) An inference on the process of gas outburst from Lake Nyos, Cameroon. J. Volc. Geotherm. Res. 39, 135-149.

Kling G. W., Clark M. A., Compton H. R., Devine J. D., Evans W. C., Humphrey A. M., Koenigsberg E. J., LockWOOd J. P., TUTTLE M. L. and WAGNER G. N. (1987) The 1986 Lake Nyos gas disaster in Cameroon, West Africa. Science 236, 169-175.

Kling G. W., Evans W. C. and Tutrle M. L. (1991) A comparative view of Lakes Nyos and Monoun, Cameroon, West Africa. Verh. Int. Verein. Limnol. 24, 11021105.

Kling G. W., Tuttle M. L. and Evans W. C. (1989) The evolution of thermal structure and water chemistry in Lake Nyos. J. Volc. Geotherm. Res. 39, 151-165.

Kusakabe M., Ohsumi T. and Aramaki S. (1989) The Lake Nyos gas disaster: chemical and isotopic evidence in waters and dissolved gases from three Cameroonian crater lakes, Nyos, Monoun, and Wum. J. Volc. Geotherm. Res. 39, 167-185.

Kusakabe M. and Sano Y. (1991) The origin of gases in Lake Nyos, Cameroon. In Natural Hazards in West and Central A frica (eds S. J. Freeth, K. M. ONuOHA and C. S. Ofoegbu), pp. 83-95. Earth Evolution Series, International Monograph Series on Interdisciplinary Earth Sciences Research and Applications. Vieweg Verlag.

Le Guern F. and Sigvaldason G. E. (eds.) (1989) The Lake Nyos event and natural $\mathrm{CO}_{2}$ degassing, I. J. Volc. Geotherm. Res. 39, 95-275.

Le Guern R. and Sigvaldason G. E. (eds.) (1990) The Lake Nyos event and natural $\mathrm{CO}_{2}$ degassing, II. J. Volc. Geotherm. Res. 42, 307-404.

Lockwood J. P. and Rubin M. (1989) Origin and age of the Lake Nyos maar. Cameroon. J. Volc. Geotherm. Res. 39. 117-124.

Lockwood J. P., Costa J. E., Tuttle M. L., NNi J. and Teror S. G. (1988) The potential for catastrophic dam failure at Lake Nyos maar, Cameroon. Bull. Volcan. 50, 340-349.

Marechal A. (1976) Geologie et geochimie des sources thermominerales du Cameroun. Office de la Recherche Scientifique et Technique d'Outre-Mer (ORSTOM), Paris

Nojiri Y., Kusakabe M., Hirabayashi J., Sato H., Shinohara H., Nuine T. and Tanyileke G. (1990) Gas discharge at Lake Nyos. Nature 346, 322-323.

Nojiri Y., Kusakabe M., Tietze K., Hirabayashi J., Sato H., Sano Y., Shinohara H., Nine T. and Tanyileke G. (1993) An estimate of $\mathrm{CO}_{2}$ flux in Lake Nyos, Cameroon. Limnol. Oceanogr. (in press).

Rowe G. L., Brantley S. L. and Borgia A. (1990) Poás volcano: heat, water and chemical fluxes in an unstable crater lake system. Trans. Am. Geophys. Un. 71, 1674.

Sabroux J. S., Villeveille A., Dubois E., Doyotte C., Halbwachs M. and Vandemeulebrouck J. (1990) Satel- lite monitoring of the vertical temperature profile of Lake Nyos, Cameroon. J. Volc. Geotherm. Res, 42, 381-385.

Sano Y., Kusakabe M., Hirabayashi J., Nojiri Y., Shinohara H., Nuine T. and Tanyileke G. (1990) Helium and carbon fluxes in Lake Nyos, Cameroon: constraint on the next lethal gas burst. Earth Planet. Sci. Lett. 99, 303-314.

Sass J. H., Kennelly J. P. JR., Wendt W. E., Moses T. H. $J_{R}$. and Ziagos J. P. (1981) In-situ determination of heat flow in unconsolidated sediments. Geophysics 46, 76-83.

Schenker R. and Dietrich V. J. (1986) The Lake Nyos gas catastrophe (Cameroon). A magmatological interpretation. Schweiz. miner. petrogr. Mitt. 66, 343-384.

Schuster R. L. and Lockwood J. P. (1991) Geologic hazards at Lake Nyos, Cameroon, West Africa. $A E G$ News 34, 28-29.

Sigurdsson H., Devine J. D., Tchoua F. M., Presser T. S., Pringle M. K. W. and Evans W. C. (1987) Origin of the lethal gas burst from Lake Monoun, Cameroon. $J$. Volc. Geotherm. Res. 31, 1-16.

TAZIEFF H. (1989) Mechanisms of the Nyos carbon dioxide disaster and of so-called phreatic steam eruptions. $J$. Volc. Geotherm. Res. 39, 109-116.

TIETzE K. (1978) Geophysikalische untersuchung des kivusees und seiner ungewohnlichen methangaslagerstatteschichtung, dynamic und gasgehelt de seewassers. Ph. D. thesis, Kiel University, Germany.

Tietze K. (1987) Results of the German-Cameroon research expedition to Lake Nyos (Cameroon) October/ November 1986. Interim-Report, Bundesanstalt für Geowissenschaften und Rohstoffe Archive no. 100470, Hannover.

Tietze K., Geyh M., Muller H., Schroder L., Stahl W and Wehner H. (1980) The genesis of the methane in Lake Kivu (Central Africa). Geol. Rdsch, 69, 452-472.

Tuttle M. L., Briggs P. H., Evans W. C., Kling G. W. and Lockwoov J. P. (1992) Influence of mafic minerals on water chemistry and water-column stability of Lake Nyos, Cameroon. In Proceedings of the 7 th International Symposium on Water-Rock Interaction (eds Y. K. KHARAKA and A. S. MAEST), pp. 449-452. Balkema.

Tuttle M. L., Clark M. A., Compton H. R., Devine J. D., Evans W. C., Humphrey A. M., Kling G. W., KoenigsBerg E. J., Lockwood J. P. and WAGNer G. N. (1987) The 21 August 1986 Lake Nyos gas disaster, Cameroon. U.S. Geol. Surv. Open-File Rept. 87-97.

WeIss R. F. (1974) Carbon dioxide in water and seawater: The solubility of non-ideal gas. Mar. Chem. 2, 203-215.

Whiticar M. J., Faber E. and Schoell M. (1986) Biogenic methane formation in marine and freshwater environments: $\mathrm{CO}_{2}$ reduction $v s$. acetate fermentation-Isotope evidence. Geochim cosmochim. Acta 50, 693-709.

Wilhelm E., Battino R. and Wilcock R. (1977) Lowpressure solubility of gases in liquid water. Chem. Rev. 77, 219-262.

Wise D. L. and Houghton G. (1966) The diffusion coefficients of ten slightly soluble gases in water at $10-60^{\circ} \mathrm{C}$. Chem. Engng Sci. 21, 999-1010. 